Morissette, J. L., E. M. Bayne, K. J. Kardynal, and K. A. Hobson. 2019. Regional variation in responses of wetland-associated bird communities to conversion of boreal forest to agriculture. Avian Conservation and Ecology 14(1):12. https://doi.org/10.5751/ACE-01355-140112

Copyright (C) 2019 by the author(s). Published here under license by the Resilience Alliance.

Research Paper, part of a Special Feature on Conservation of Boreal Birds

\title{
Regional variation in responses of wetland-associated bird communities to conversion of boreal forest to agriculture
}

\author{
Julienne L. Morissette ${ }^{1}$, Erin M. Bayne ${ }^{1}$, Kevin J. Kardynal ${ }^{2}$ and Keith A. Hobson ${ }^{2,3}$ \\ ${ }^{1}$ Department of Biological Sciences, University of Alberta, Edmonton, AB, Canada, ${ }^{2}$ Environment \& Climate Change Canada, \\ Science and Technology Branch, ${ }^{3}$ Department of Biology, Western University
}

\begin{abstract}
Globally and in Canada's boreal forest, extensive deforestation has occurred because of agricultural conversion. However, consequences of forest loss for bird assemblages associated with wetlands and their associated riparian areas and shoreline forests are poorly understood. Using the multivariate approach, Threshold Indicator Taxa Analysis (TITAN), we assessed the response of bird communities to an agricultural conversion gradient at two spatial scales: (1) locally within $500 \mathrm{~m}$ of a wetland, and (2) throughout a $5 \times 5 \mathrm{~km}$ landscape. We compared results from a study area in Manitoba surrounded by agriculture (DMMB) to those from a landscape where agriculture is encroaching from the southern edge in east-central Alberta (ECAB). Both species-level and community-level changes tended to occur at lower levels of agricultural conversion in DMMB than in ECAB, particularly at the landscape scale. Community-level changes were more gradual and reached a single maximum at the wetland scale, whereas there were two to three distinct community-level change-points at the landscape scale. Species responding positively (15 in ECAB and 18 in DMMB) to agricultural conversion were typical of open-country ecoregions, while species that responded negatively (13 in each of ECAB and $\mathrm{DMMB}$ ) tended to be those for which loss of forest cover represented direct loss of habitat. For species common to both regions, direction of response (+ or -) was typically consistent, but specific change-points differed. Where conversion of forest to agriculture is unavoidable in boreal forests, limiting the total amount of forest and wetland vegetation loss around wetlands and within the landscape matrix to $\leq 30 \%$, along with wetland preservation, will have the greatest benefit to conserving bird communities typical of boreal wetlands and their adjacent riparian areas and forests.
\end{abstract}

\section{Variation régionale des communautés d'oiseaux associés aux milieux humides en réponse à la conversion de la forêt boréale en terres agricoles}

RÉSUMÉ. Partout sur la planète ainsi que dans la forêt boréale canadienne, on a défriché les forêts à grande échelle pour les convertir en terres agricoles. Toutefois, les conséquences de ces pertes de forêts sur les assemblages d'oiseaux associés aux milieux humides et leurs bandes riveraines et forestières adjacentes sont mal connues. Au moyen de l'approche multivariée TITAN (Threshold Indicator Taxa Analysis), nous avons évalué la réaction d'une communauté d'oiseaux en fonction d'un gradient de conversion agricole à deux échelles spatiales : 1) localement à l'intérieur de $500 \mathrm{~m}$ d'un milieu humide; et 2) dans un paysage de $5 \times 5 \mathrm{~km}$. Nous avons comparé les résultats provenant d'un site d'étude entouré de terres agricoles au Manitoba (DMMB) à ceux d'un paysage dans lequel l'agriculture empiète à la bordure sud dans le centre-est de l'Alberta (ECAB). Sur le plan des espèces comme sur celui des communautés, les changements ont eu tendance à se produire à des niveaux de conversion agricole plus faible dans DMMB que dans ECAB, particulièrement à l'échelle du paysage. Les changements au niveau de la communauté ont été plus graduels et ont atteint un unique maximum à l'échelle du milieu humide, tandis qu'il y a eu de 2 à 3 points de changements distincts de la communauté à l'échelle du paysage. Les espèces ayant réagi positivement aux conversions agricoles (15 dans ECAB et 18 dans DMMB)étaient typiques d'écorégions de milieux ouverts, alors que les espèces ayant réagi négativement (13 dans ECAB et 13 dans DMMB) avaient tendance à être celles pour lesquelles les pertes de forêts représentaient des pertes directes d'habitat. Pour les espèces communes aux deux régions, le sens de la réponse (+ ou -) était similaire, mais les points où se sont produits les changements spécifiques ont différé. En forêt boréale, là où les conversions de forêts en terres agricoles sont inévitables, le fait de limiter la perte de forêt et de végétation autour des milieux humides et dans le paysage à $\leq 30 \%$, combiné avec la préservation des milieux humides, offrira les bénéfices les plus importants pour conserver les communautés d'oiseaux caractéristiques des milieux humides boréaux et leurs bandes riveraines et forestières adjacentes.

Key Words: agriculture; biotic homogenization; boreal bird; community change; forest conversion; fragmentation

\section{INTRODUCTION}

Worldwide, loss and fragmentation of forests due to agricultural conversion is one of the largest causes of biodiversity decline (Pereira et al. 2012, Wilcove et al. 2013, Perrings and Halkos 2015). Agricultural expansion and intensification has also resulted in loss and degradation of wetlands and riparian areas in forested areas because of drainage, eutrophication, pesticide use, and use as water sources for cattle (Tilman et al. 2001, Houlahan and Findlay 2004). Between 1951 and 1999, the boreal forest of western Canada experienced annual rates of deforestation on privately owned lands from $0.87 \%$ to $1.76 \%$ annually (Hobson et al. 2002). Increased human disturbance from forestry, oil and gas 
development, and agricultural activity in that region has generally resulted in concomitant changes in wildlife communities (Hobson and Bayne 2000, Venier et al. 2014), altered predator-prey dynamics (Hannon and Cotterill 1998, DeMars and Boutin 2018), lowered productivity, and population declines for some taxa (Bayne and Hobson 1997, Hobson and Bayne 2000, Cumming et al. 2001, Venier et al. 2014).

Relative to other biomes, the entire North American boreal forest is among the least affected by agricultural conversion (Hoekstra et al. 2004, Hansen et al. 2013); however, in western Canada's boreal plains, as much as $48 \%$ of the forested area is considered at risk of being converted to agriculture (Hobson et al. 2002). Expansion of human activities in the boreal forest continues to occur and the suitability of some areas for agriculture is anticipated to increase with projected climate change, suggesting that the risk of deforestation due to agricultural conversion will continue to grow (Ramankutty et al. 2002, Zhang and Cai 2011, Zabel et al. 2014, Gauthier et al. 2015). Combined with drier conditions expected with climate change and other impacts of agriculture, further loss and degradation of boreal forest wetlands and riparian areas appears likely (Foote and Krogman 2006, Tarnocai 2009, Bayley et al. 2013). More recently, many regions are developing or have adopted wetland policies, regulations, and financial incentives that try to conserve remaining wetlands in previously forested regions. However, depending on regulatory context, these practices typically consider a limited range of wetland types and protect only the wetland itself and occasionally small amounts of adjoining riparian areas and shoreline forests (Foote and Krogman 2006, Bauer et al. 2010). This type of protection and management does not consider landscape-scale effects that may also be influencing biodiversity in these areas. A better understanding of responses of wetland and riparian biodiversity to these changes will be crucial to evaluating the success of wetland conservation initiatives in forested landscapes undergoing conversion to agriculture.

Local habitat conditions and land uses are undoubtedly important for biodiversity maintenance adjacent to wetlands (Saab 1999, Bauer et al. 2010). There is also increasing evidence to suggest that the loss of forest around wetlands and riparian areas at broader scales may also have negative effects on wetland functioning and biodiversity (Saab 1999, Rodewald and Bakermans 2006, Lougheed et al. 2008). Anthropogenic disturbances at landscape scales can impact local wetland biodiversity via changes in hydrological processes, water quality, invasive species, landscape connectivity, and biotic homogenization (Haig et al. 1998, Guadagnin and Maltchik 2007, Rooney and Bayley 2011, Tsai et al. 2012). These effects are expected to be greatest where species track temporally variable resources, e.g., insect emergences, or concurrently require different parts of the landscape, e.g., species that forage over water and nest in tree cavities. Thus, riparian and wetland bird species may be disproportionally affected by changes in the surrounding landscape matrix despite the appearance that core habitat including shoreline forests, riparian areas, and the wetland itself appear relatively intact (Houlahan et al. 2006).

One approach to quantifying changes in both terrestrial and aquatic ecosystems is the determination of ecological thresholds, defined as zones or points where an abrupt change in an ecosystem property occurs in response to an environmental driver
(Groffman et al. 2006). In general, evidence for density or population thresholds has been equivocal with results being metric-, scale- and species-dependent (Swift and Hannon 2010). Further, when community-level metrics such as diversity and species richness are used to determine thresholds, their application in an environmental management context becomes problematic. These metrics obscure species-specific changes and do not distinguish between positively responding and negatively responding species even though these responses to land use changes are potentially important management tools. For example, positively responding species often contribute to species richness in areas of intermediate disturbance (Shea et al. 2004, Lepczyk et al. 2008). However, species identity confirms species responding positively to novel gradients such as human disturbances are frequently non-native (Ervin et al. 2006) or species generalists (Devictor and Robert 2009). Increases in species richness may also mask declines in the occurrence and abundance of native species and specialists. In cases where thresholds in species richness and diversity have been identified, ecological interpretation often also includes caveats that a rapid decrease in species richness represents the "endpoint of extinction processes for multiple species" (Radford et al. 2005:333).

Hilderbrand et al. (2010) suggested the use of an "initiation of impact" threshold, based on a minimum detectable response and defined as a zone or point at which disturbances or stressors begin to affect organisms negatively (as measured by relative abundance and frequency of occurrence). This approach is potentially useful in predictive models and environmental management because determining an "initiation of impact" could provide managers an estimate of levels of a particular land use practice approaching a critical habitat threshold and potentially nonreversible change (Groffman et al. 2006). Indeed, there are several definitions for and approaches to determining thresholds (Swift and Hannon 2010). However, for these types of thresholds to be practically applied, they also must be generalizable and applicable at scales suitable for management. Recognizing patterns of species-level and community composition change relative to the amount of forest cover around wetlands will help to inform managers about which wetlands should be conserved if the objective is to maintain avian wetland communities consistent with those in forested ecosystems. Methods that detect contributions of individual taxa to community change along novel environmental gradients (e.g., Baker and King 2010) and thus provide an index of whether community level thresholds have occurred are more informative and allow managers to assess both species-level trade-offs as well as broader community level implications of land use change.

To examine probable drivers influencing distribution and abundances of species, many authors have used a multiscaled approach to assess the relative importance of local habitat features affecting communities and influences of the broader landscape context on the distribution abundance and dynamics of birds (Saab 1999, Kennedy et al. 2011). In the context of identifying thresholds in abundance or frequency of occurrence at the scale of the patch (local habitat), changes may appear abrupt because of the sudden loss of a key species (Chapin et al. 2004). At a landscape-scale, transitions may appear more gradual because of changes being distributed over increased space and time (Radford et al. 2005). Because most bird species are ecologically linked, directly or indirectly, to both terrestrial and aquatic ecosystems 
in some way via riparian areas and wetlands, we consider avian assemblages in shoreline forests and riparian areas as "trophic links" between terrestrial and aquatic systems (Larsen et al. 2010).

Herein, we studied avian assemblages at boreal wetlands, riparian areas and shoreline forests along a gradient of agricultural conversion at two nested scales: individual wetlands and wetlands within $5 \times 5 \mathrm{~km}$ landscapes. We set out to (1) characterize specieslevel changes in response to increasing levels of conversion of forest to agriculture, (2) determine whether these change-points resulted in community-level thresholds, (3) determine whether these thresholds were consistent when habitat loss was measured at local- and landscape-scales, and (4) compare these responses in two different regions of the Boreal Plain ecozone western Canada within different broader-scale land uses. Since birds typically occurring in late-seral forest stages are more sensitive to agricultural conversion than early successional species and generalist species (Hobson and Bayne 2000), we expected species typically associated with riparian areas and wetlands to be more tolerant of changes in the surrounding habitat matrix than those typically associated with areas of intact forest. However, we also expected some species that require both wetland and upland habitats (e.g., Bufflehead Bucephala albeola) to have reduced abundance in areas with higher amounts of agriculture.

\section{METHODS}

\section{Study areas}

We conducted our research in two study areas within the Boreal Plains ecozone (Fig. 1; Environment Canada 2005) in east-central Alberta (ECAB; $\left.56^{\circ} 52^{\prime} \mathrm{N}, 115^{\circ} 27^{\prime} \mathrm{W}\right)$ and in the Duck Mountain (DMMB; $51^{\circ} 39^{\prime} \mathrm{N}, 100^{\circ} 57^{\prime} \mathrm{W}$ ) in southwestern Manitoba and southeastern Saskatchewan. Both study areas are situated within or near the southern fringe (Boreal Transition ecoregion) of the Boreal Plains ecozone (Ecological Stratification Working Group 1996). The climate is generally dry with evapotranspiration rates slightly exceeding precipitation (Petrone et al. 2007). The landscape ranges from extensively cleared to intact mosaics of mixedwood and deciduous forests (Hobson et al. 2002). Agricultural activity in both study areas date back to the late 1800s and included conversion of forest to pasture for livestock grazing and annual cropping, e.g., canola, barley, wheat. Other human land use activities in these areas include sparse urban and municipal developments, exploration and extraction of oil and natural gas (Alberta only), forest harvesting, and recreational trails. Although the overall distribution of wetlands and landscapes along the disturbance gradient were similar, the two study areas differed in that DMMB is a forested escarpment almost completely embedded in a matrix of agricultural lands; the gradient of conversion to agriculture takes place over a short geographic distance and is more absolute. In Alberta, agricultural conversion sites were embedded in a forested landscape matrix where distances to large areas of forest were shorter and more frequent.

Wetlands including marsh, swamp, fen, bog, and open water classes account for between $20-60 \%$ of the total study area (Vitt et al. 1994, Trettin et al. 1996). Our research focused on open water wetlands and their adjacent riparian areas and shoreline forests between open water and upland habitats that often comprise one or more wetland classes (Locky et al. 2005, Whitehouse and Bayley 2005). Upland forests occur as pure or mixed stands of any combination of trembling aspen (Populous tremuloides), white spruce (Picea glauca), balsam fir (Abies balsamea), and jack pine (Pinus banksiana) depending on soil characteristics, disturbance history, and topography. Dominant tree species in forested wetlands (lowland) sites include balsam poplar (Populous balsamifera), white birch (Betula papyrifera), black spruce (Picea mariana), and tamarack (Larix laricina).

\section{Landscape selection}

Using Geographic Information Systems (GIS) and roving window analysis, we generated a set of all possible $5 \times 5 \mathrm{~km}$ "landscapes" in each study area. This landscape size was selected because it reflected the mean topographic catchment size for DMMB (Louisiana Pacific Canada Ltd. 1995), could easily contain five open water wetlands $\geq 500 \mathrm{~m}$ apart, and encompassed a broad range of regionally representative forest and wetland types. We assessed each landscape for forest composition (i.e., forest type), wetland size and abundance, and amount of agricultural conversion using a classified Landsat TM imagery from 2002 and 2003 (Ducks Unlimited Canada, unpublished data). From these, we selected a subset of individual landscapes for further study: (a) located $\leq 2 \mathrm{~km}$ from a road in order to facilitate access, (b) presence of at least five discrete open-water wetlands (see below), (c) forest-stand composition prior to human disturbance of $>50 \%$ aspen and aspen-mixed wood forests, i.e., not dominated by peatlands, and (d) were not adjacent to another study landscape. Landscapes containing recent fires ( $<30$ years) and forestry activity were excluded. Because we used remotely sensed habitat data to quantify agricultural disturbance, we grouped all crop types and pastures into one agricultural disturbance class because these may change annually. Landscapes were then randomly selected from a pool of suitable landscapes representing a gradient of conversion to agriculture (range: 0 $90 \%)$.

\section{Wetland selection}

In each landscape, we randomly selected five shallow, open water wetlands (2-16 ha) that were at least $500 \mathrm{~m}$ apart to survey the bird community. We visited each wetland prior to the bird survey period to determine a location at the wetland best suited for obtaining an inventory of a representative portion of the bird community, i.e., survey available habitats. When necessary, preselected wetlands that were inaccessible by land were replaced with alternate accessible wetlands. In some landscapes, particularly those with high amounts of agricultural conversion, we were unable to find five wetlands meeting our size requirements or a suitable alternate landscape. In these instances, we selected suitable wetlands $<3 \mathrm{~km}$ from an associated landscape boundary to be used only in wetland scale analyses (below). Similar to the landscape-scale analyses, we calculated area of forest and agriculture within $500 \mathrm{~m}$ of the wetland perimeter. We then converted area calculations to proportions to account for difference in total area due to wetland shape and size for inclusion in our models.

\section{Bird surveys}

We conducted bird surveys between 1 June-5 July in 2003 and 2004 in ECAB and 2005 in DMMB. To maximize the number of 
Fig. 1. Locations of study areas in the Boreal Plains ecozone in east-central Alberta (ECAB) and Duck Mountain (DMMB), Manitoba and Saskatchewan, Canada. The Boreal Transition ecoregion is part of the Boreal Plains ecozone and is characterized by the presence of both arable land for agriculture and the southern limit of boreal forest (Ecological Stratification Working Group 1996).
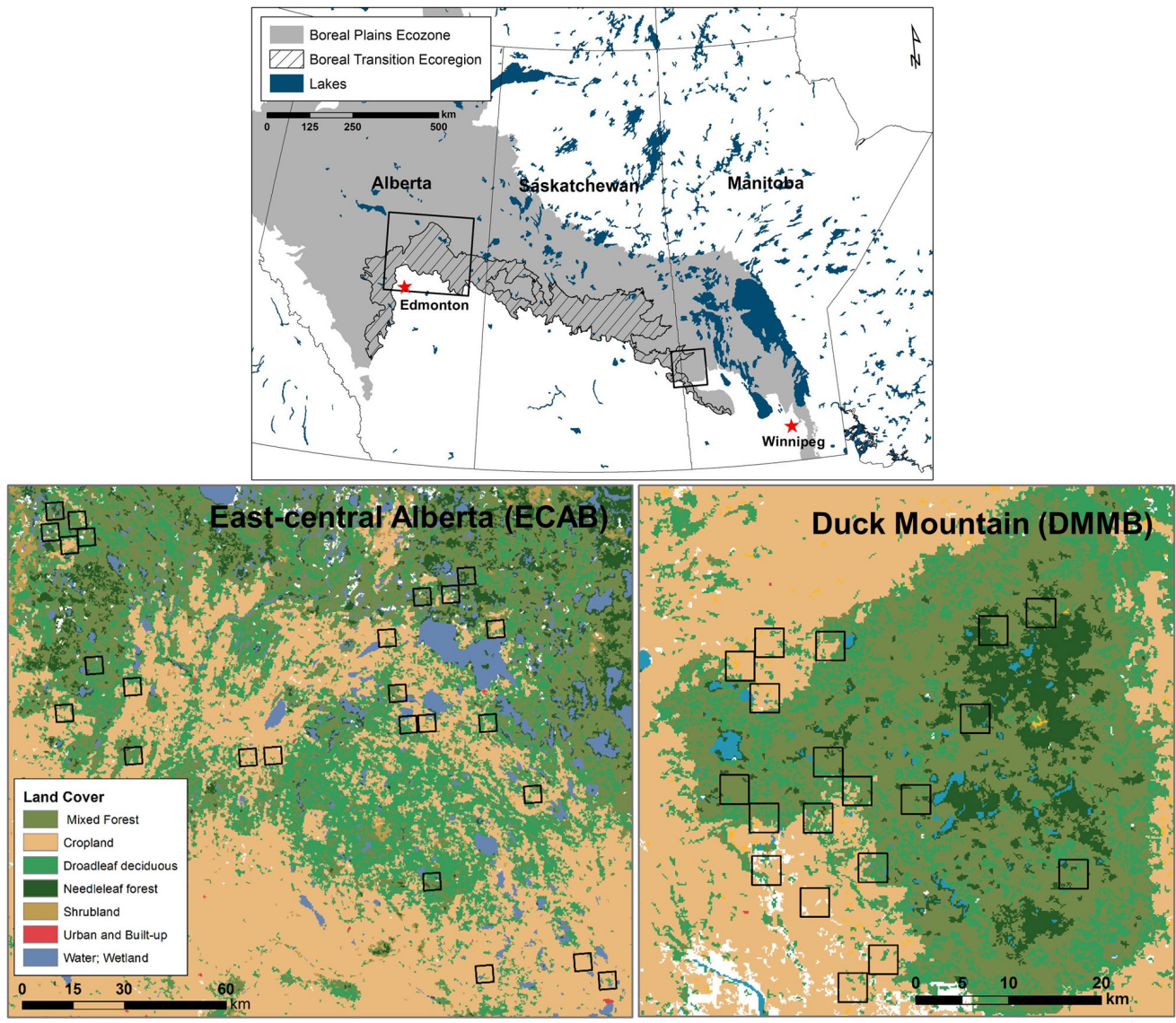

sites surveyed along the agricultural gradient, we sampled many wetlands once rather than conducting repeated visits at fewer sites (Carlson and Schmiegelow 2002). Bird surveys began no earlier than 30 minutes before sunrise, ended no later than five hours after sunrise and were conducted only on days with little or no wind and no rain. The order of wetlands surveyed within a landscape was randomized to ensure that sampling wetlands of different sizes and amount of adjacent agricultural conversion was unbiased. Each wetland was surveyed once. Observers were also randomly assigned wetlands to survey.

At each wetland, we used a series of survey techniques to maximize bird detections in upland, riparian, and aquatic habitats. First, we conducted a stationary 20-minute waterfowl visual point-count using binoculars and a spotting scope, followed by a 10 -minute, fixed-radius $(100 \mathrm{~m})$ point-count for land birds and concluded the survey with a 5-minute playback for five nonpasserine wetland bird species common in the area (Conway 2011). Birds in flight were not counted unless they landed within the survey area, i.e., wetland, during the appropriate survey period. Because the productivity and diversity of riparian areas can generally be attributed to biotic and nutrient exchanges between terrestrial and aquatic areas, we treated aquatic, wetland, and upland bird assemblages as a single community (Croonquist and Brooks 1991). All observers received annual audio census training and we compared trial counts across individual observers prior to the survey period to improve consistency. Timing of surveys (early or late morning and day within the breeding season) for each landscape was randomized across the disturbance gradient and among observers to reduce potential sampling biases (Bibby et al. 2000). Counts of birds using different methods, i.e., waterfowl, passerine, and marsh bird, at individual wetlands were pooled to represent the bird community for the wetland-scale analysis. Similarly, for analysis at the landscape-scale, counts from the five wetlands from within the corresponding $5 \times 5 \mathrm{~km}$ landscape were aggregated as the total number of individuals of all species seen across all five wetlands within a given landscape.

\section{Statistical analysis}

We used Threshold Indicator Taxa Analysis (TITAN; Baker and King 2010) to identify species-specific change-points along a gradient of boreal forest conversion to agriculture. TITAN uses indicator values (IndVal) from indicator species analysis (ISA), 
which compares both relative abundances and frequencies of species, to identify species-specific change-points along the gradient. Midpoints between observed values along the environmental gradient are identified as candidate change-points, which are then used to iteratively divide observations into a candidate species group showing a positive response with respect to the environmental gradient and another group showing a negative response. TITAN examines the relative synchrony and uncertainty among individual species change-points as a nonparametric estimator of an overall community threshold and distinguishes between positive and negative responses to an environmental gradient. In this analysis, larger differences between indicator values on each side of a candidate change-point receive greater indicator value scores signifying a good indicator species. The largest of these two indicator value scores are retained for comparison with values at other candidate change-points. We used 250 permutations of the data to estimate the probability of obtaining an equal or greater indicator value score from random data (Dufrêne and Legendre 1997).

Confidence intervals around change-points (percentiles) as well as consistency ("purity") of the response direction (positive or negative) of each species are estimated using a bootstrap procedure with 500 iterations. A high purity level ( 1) means species are consistently assigned the same response direction expressed as the proportion of change-point directions among bootstrap replicates that agree with the observed response. Confidence limits for species with low occurrence frequencies were interpreted with caution because these may be unreliable regardless of the method used (Manly 1997, Baker and King 2010). The proportion of change-point indicator value scores (IndVal) among the bootstrap replicates that consistently have pvalues below defined probability levels (in our case 0.05 ) is referred to in this analysis as "reliability." Reliable indicators (reliability $\geq$ 0.95) are those with consistently large IndVal. Following the individual species analysis, we used TITAN to estimate community thresholds along the environmental gradient derived by estimating synchronous changes by either positively or negatively responding taxa. We calculated and plotted community thresholds using the sum of the standardized indicator values, referred to as $\operatorname{sum}(z)$, which indicate overall negative or positive $\operatorname{sum}(z)$ affinity to the gradient by species groups. Peaks or maxima in $\operatorname{sum}(z)$ values, whether positive or negative, indicate that synchronous change in many taxa can be interpreted as community thresholds along the disturbance gradient.

We conducted the TITAN analysis separately at both wetland and landscape-scales for each study area. Species with abundances of $<5$ and occurrences of $<3$ were excluded from the analyses (De'ath and Fabricius 2000, Baker and King 2010) and BrayCurtis and Euclidian dissimilarities were used for all calculations (McCune and Grace 2002). Indicator values for both negative and positive species were considered significant at $p<0.05$ and purity and reliability $\geq 0.95$. All analyses were performed with a modified version of TITAN package in R.1.2.1 (Baker and King 2010). Although the TITAN method has been critiqued (Cuffney and Qian 2013) the approach and the above criteria are those recommended by the developers of TITAN and have been shown to give repeatable and accurate results (Baker and King 2010, 2013).

\section{RESULTS}

In the ECAB study area (2003-2004), we surveyed 25 landscapes and 140 wetlands resulting in 5231 bird records. We obtained data for 114 species; however, only 75 species were sufficiently abundant to be retained in the analyses. In 2005, we conducted our study in the DMMB study area recording 4720 detections representing 103 species at 36 landscapes and 180 wetlands. There, 82 species were sufficiently abundant to be retained for analysis.

\section{Wetland-scale community and species-level responses}

In the ECAB within $500 \mathrm{~m}$ of wetlands, TITAN identified 13 species having significant negative responses between 10-64\% total conversion to agriculture, e.g., Common Loon Gavia immer, Ovenbird Seiurus aurocapilla, Hermit Thrush Catharus guttatus (Fig. 2A; Table A1.1A in Appendix 1; Fig. A2.1A in Appendix 2). At this scale, 19 species had significant positive responses between $8-70 \%$ conversion, e.g., Brown-headed Cowbird Molothrus ater, Yellow Warbler Setophaga petechia, Clay-colored Sparrow Spizella pallida. Negatively responding species, i.e., sum (z-) values, increased at low levels of agricultural conversion, but occurred regularly along the gradient resulting in a cumulative threshold frequency that was reached at $40 \%$. Positively responding species, i.e., $\operatorname{sum}\left(\mathrm{z}^{+}\right)$values, peaked quickly before $20 \%$ and showed additional peaks at $30 \%$ and $40 \%$ and $50 \%$ (cumulative threshold frequency peaked at 60\%) suggesting continued gradual species colonization throughout the gradient (Fig. A3.1A in Appendix 3).

In the DMMB study area at $500 \mathrm{~m}$, peaks in both increasing and decreasing species occurred at the low end of the total disturbance gradient, at just $10 \%$ agricultural conversion. Subsequent species declines or species increases occurred gradually throughout the entire disturbance gradient. Cumulative threshold frequencies peaked at $40 \%$ for negatively responding species and at $80 \%$ for positively responding species. Five species, Red-breasted Nuthatch (Sitta canadensis), Ruby-crowned Kinglet (Regulus calendula), Common Loon, Yellow-rumped Warbler (Setophaga coronata), and Swainson's Thrush (Catharus ustulatus) had negative thresholds at $10 \%$ conversion to agriculture within 500 $\mathrm{m}$ of the wetland (Fig. 3A; Table A4.1A in Appendix 4; Fig. A5.1A in Appendix 5). Negative thresholds for five other species, Mourning Warbler (Geothlypis philadelphia), Ovenbird, Chipping Sparrow (Spizella passerina), and Swamp Sparrow (Melospiza georgiana) were calculated between $10-40 \%$. At the wetland scale, 18 species, e.g., Song Sparrow (Melospiza melodia), Red-winged Blackbird (Agelaius phoeniceus), and Redhead (Aythya americana) showed positive responses as conversion to agriculture increased and these occurred gradually along the entire conversion gradient, a pattern that was also reflected in the community-level results (Fig. A6.1A in Appendix 6).

\section{Landscape-scale community and species- level responses}

In general, many of the species found to be significant indicators at the wetland-scale were also significant at the landscape-scale, but there were several additional species showing a negative response for both study areas, e.g., Boreal Chickadee Poecile hudsonicus (Figs. A2.1B and A5.1B, Appendices 2 and 5). We found substantial differences in community-level responses 
Fig. 2. Threshold Indicator Taxa Analysis (TITAN; Baker and King 2010) of the response of bird assemblages to proportion of conversion of boreal forest to agriculture for the east-central Alberta study area at the (A) landscape scale ( 5 wetlands in $5 \times$ $5 \mathrm{~km}$ area), and (B) within $500 \mathrm{~m}$ of a wetland. Figures in the left column represent community-level responses to the disturbance gradient. Peaks in $\operatorname{sum}(\mathrm{z})$ values represent points at which synchronous species increases $\left(\mathrm{z}^{+}\right)$or declines $(\mathrm{z}-)$ are occurring. Solid and dashed lines represent cumulative frequency distribution of change-points ( $\mathrm{Cp}$ thresholds among 500 bootstrap replicates). Figures in the right-hand column represent species-level responses to the disturbance gradient. Species are plotted in increasing order of change-point. Solid symbols correspond to negative indicator species (z-) and open symbols correspond to positive indicator species $\left(z^{+}\right)$. Symbols are sized in proportion to the magnitude of the response (larger symbols represent higher z-values). Lines through the symbols represent the extent of the 5th and 95th percentiles. See Appendix 1 for species common and scientific names, and associated values. Scatter plots of the abundance of each species against a gradient of agricultural conversion are found in Appendices 2 (negative) and 3 (positive).
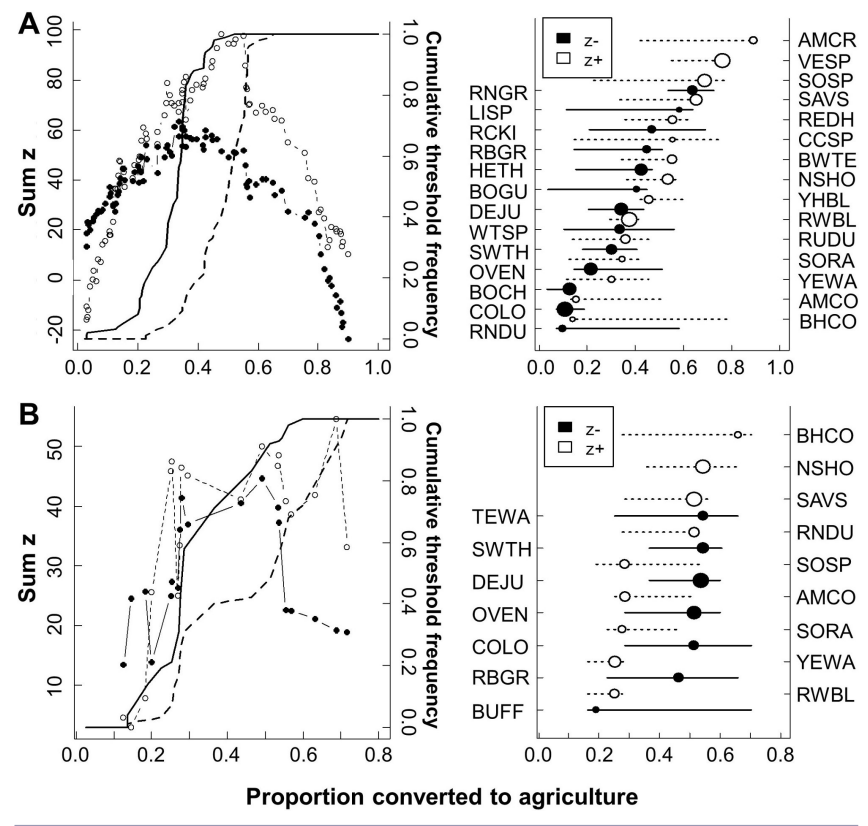

between regions to a gradient of agricultural conversion (Table 1, Figs. 2 and 3). In the ECAB study area, TITAN identified an overall community change-point at $51 \%$ agricultural cover for taxa responding negatively and of $70 \%$ for taxa responding positively (Table 1). In the DMMB study area, these values were $14 \%$ and $40 \%$, respectively. However, confidence intervals around all community-level thresholds were quite large ( $\pm 39-53 \%)$ and once plotted, $\operatorname{sum}(\mathrm{z})$ values indicated more than one point where synchronous changes (peaks in $\operatorname{sum}(z)$ values) occurred (Figs. 2 and 3). Together, these results suggest there is no strong evidence for community-level thresholds in either study area when the entire (riparian, wetland, and forest) bird community is grouped for analysis. Distance-based results are provided for comparison in Table 1.
Table 1. Bird community change-point $(\mathrm{Cp})$ results from Threshold Indicator Taxa Analysis (TITAN) at landscape $(5 \times 5$ $\mathrm{km}$ ) and $500 \mathrm{~m}$ (around wetlands) scales along a gradient of boreal forest conversion to agriculture for surveys conducted at individual wetlands in (a) northeastern Alberta (ECAB) and (b) Duck Mountain, Manitoba/Saskatchewan (DMMB), Canada. Values for $5 \%, 10 \%, 50 \%, 90 \%$, and $95 \%$ quantiles are included. For comparison, results of typical change-point analyses that examine ecological distances (ncpa.bc, ncpa.euc) without considering direction of the species responses are also included.

\begin{tabular}{|c|c|c|c|c|c|c|}
\hline & $\mathrm{Cp}$ & 0.05 & 0.10 & 0.50 & 0.90 & 0.95 \\
\hline \multicolumn{7}{|l|}{ ECAB - Landscape } \\
\hline $\operatorname{sum}(z-)$ & 0.51 & 0.16 & 0.19 & 0.29 & 0.51 & 0.56 \\
\hline $\operatorname{sum}(z+)$ & 0.70 & 0.25 & 0.26 & 0.53 & 0.70 & 0.72 \\
\hline ncpa.bc ${ }^{\dagger}$ & 0.51 & 0.23 & 0.26 & 0.46 & 0.56 & 0.60 \\
\hline ncpa.euc ${ }^{\star}$ & 0.51 & 0.23 & 0.25 & 0.36 & 0.60 & 0.66 \\
\hline \multicolumn{7}{|l|}{$\mathrm{ECAB}-500 \mathrm{~m}$} \\
\hline $\operatorname{sum}(\mathrm{z}-)$ & 0.34 & 0.18 & 0.21 & 0.34 & 0.42 & 0.44 \\
\hline $\operatorname{sum}\left(z^{+}\right)$ & 0.49 & 0.33 & 0.35 & 0.51 & 0.57 & 0.57 \\
\hline ncpa.bc & 0.35 & 0.17 & 0.21 & 0.33 & 0.42 & 0.46 \\
\hline ncpa.euc & 0.35 & 0.15 & 0.17 & 0.33 & 0.52 & 0.55 \\
\hline \multicolumn{7}{|l|}{ DMMB - Landscape } \\
\hline $\operatorname{sum}\left(z^{-}\right)$ & 0.14 & 0.01 & 0.01 & 0.08 & 0.32 & 0.40 \\
\hline $\operatorname{sum}\left(z^{+}\right)$ & 0.40 & 0.14 & 0.30 & 0.56 & 0.67 & 0.68 \\
\hline ncpa.bc & 0.14 & 0.03 & 0.03 & 0.21 & 0.56 & 0.56 \\
\hline ncpa.euc & 0.40 & 0.03 & 0.07 & 0.40 & 0.60 & 0.60 \\
\hline \multicolumn{7}{|l|}{ DMMB - $500 \mathrm{~m}$} \\
\hline $\operatorname{sum}\left(z^{-}\right)$ & 0.17 & 0.01 & 0.02 & 0.17 & 0.33 & 0.40 \\
\hline $\operatorname{sum}\left(z^{+}\right)$ & 0.43 & 0.38 & 0.42 & 0.50 & 0.77 & 0.79 \\
\hline ncpa.bc & 0.24 & 0.02 & 0.06 & 0.32 & 0.44 & 0.50 \\
\hline ncpa.euc & 0.42 & 0.17 & 0.28 & 0.35 & 0.50 & 0.56 \\
\hline \multicolumn{7}{|c|}{$\begin{array}{l}\text { "ncpa.bc: nonparametric community change point using Bray-Curtis } \\
\text { distance } \\
\vdots \text { ncpa.euc: nonparametric community change point using Euclidian } \\
\text { distance }\end{array}$} \\
\hline
\end{tabular}

At the landscape-scale in ECAB, synchronous changes in decreasing species occurred at $30 \%$ and at $50 \%$ agricultural conversion (Table 1; Fig. 2B). Peaks in increasing species were apparent at each of $25 \%, 50 \%$, and $70 \%$ conversion with an overall community threshold calculated at $70 \%$. At the landscape-scale, TITAN identified seven significant declining indicator species (negative response to gradient). Bufflehead (Bucephala albeola) showed a maximum change-point at $19 \%$ conversion with confidence intervals spanning most of the gradient, while the remaining six species reached their maximum change-points between 45-54\% agricultural conversion (Table A1.1B and Fig. A2.1B in Appendices 1 and 2, respectively). Nine species showed positive changes with five of these occurring in the $25-29 \%$ conversion range, e.g., Red-winged Blackbird and Yellow Warbler, three between 51-55\%, e.g., Ruddy Duck (Oxyura jamaicensis), Savannah Sparrow (Passerculus sandwichensis), and Brown-headed Cowbird at $60 \%$ conversion (Fig. 2B; Table A1.1B in Appendix 1; Fig. A3.1B in Appendix 3). Bootstrapped percentile values for all significant indicator species are listed in Table A1.1B in Appendix 1.

In DMMB, landscape-scale community responses for declining taxa peaked at $20 \%$ with relatively high sum(z-) values up to $40 \%$ conversion (Fig. 3B; Table A4.1B in Appendix 4). This was likely 
Fig. 3. Threshold Indicator Taxa Analysis (TITAN; Baker and King 2010) of bird community response to proportion of conversion of boreal forest to agriculture for the Duck Mountain study area at the landscape scale ( 5 wetlands in $5 \times 5$ $\mathrm{km}$ area), and within $500 \mathrm{~m}$ of a wetland, respectively, in Manitoba/Saskatchewan, Canada. See Figure 2 for interpretive details. Scatter plots of the abundance of each species against a gradient of agricultural conversion are found in Appendices 5 (negative) and 6 (positive).
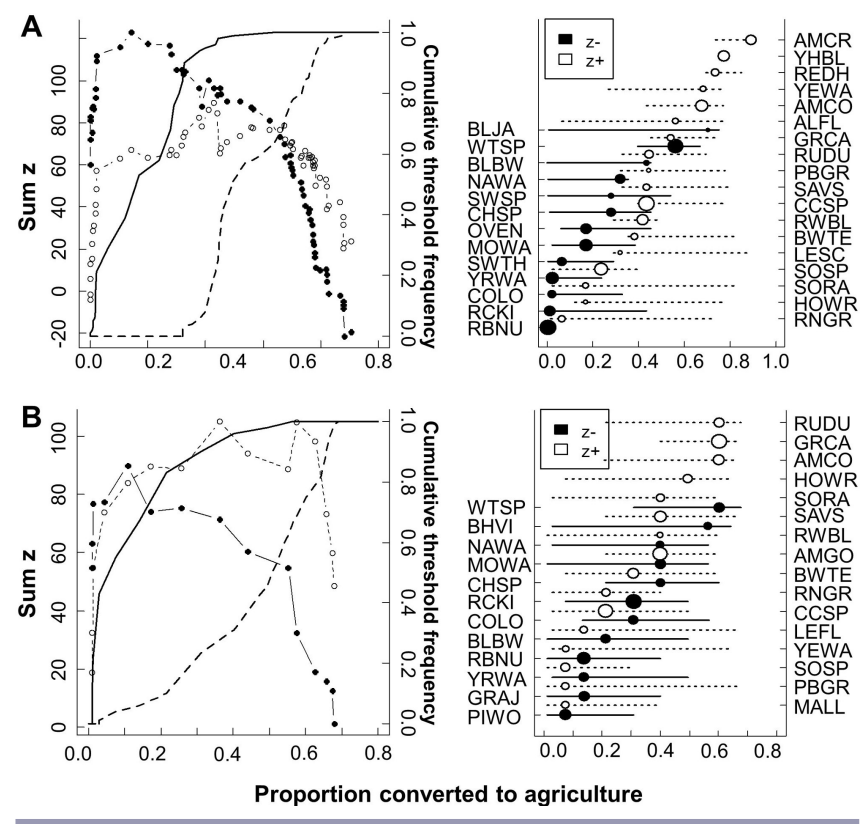

due to species showing maximal change-point values throughout the agricultural conversion gradient. Three species showed maximum change-points at $8-15 \%$ agriculture (e.g., Pileated Woodpecker Dryocopus pileatus, Yellow-rumped Warbler), Blackburnian Warbler (Setophaga fusca) at 20\%, Common Loon and Ruby-crowned Kinglet at 30\%, three species at 40\% (e.g., Chipping Sparrow, Mourning Warbler), and Blue-headed Vireo (Vireo solitarius) and White-throated Sparrow (Zonotrichia albicollis) at 50-60\% agriculture (Fig. A5.1B in Appendix 5). In this study area, 17 species also responded positively to total disturbance (Fig. A6.1B in Appendix 6). Twelve of these had change-points in the highest range where agricultural conversion was between 40 and 60\% (e.g., Ruddy Duck, Gray Catbird Dumetella carolinensis, American Coot Fulica americana), but four species had change-points before $20 \%$ total disturbance (e. g., Mallard Anas platyrhynchos, Yellow Warbler; Fig. 3B). With the entire community considered, TITAN identified a peak change-point at $40 \%$ total disturbance for positively responding species (Table 1).

\section{DISCUSSION}

Avian communities associated with boreal forest are threatened by conversion of forest to agriculture. Those communities associated with boreal wetlands are especially interesting because while wetlands may remain relatively intact following agricultural conversion, upland forest surrounding the wetlands is removed or highly altered. We present the first examination of threshold responses of wetland-and riparian-associated birds to forest loss around wetlands and in the surrounding landscape. The TITAN methodology allowed us to differentiate species with positive responses to agricultural conversion from those with negative responses. Further, this approach permitted us to combine species-level responses, either positive or negative, and assess whether community-level thresholds occurred along a gradient of agricultural conversion in the landscape matrix were consistent. In general, increasing amounts of agricultural conversion resulted in declining boreal specialist species including some wetland- and riparian-associated species, while generalist species tended to become dominant. Our results confirmed that responses of wetland-associated birds to deforestation depended on a variety of factors that need to be considered within the broader realm of boreal forest conservation (Saab 1999, Börger and Nudds 2014).

\section{Species-level responses to agricultural conversion}

Many species exhibited significant and reliable change-points with increasing amounts of agricultural conversion at both local $(500 \mathrm{~m})$ and landscape scales. Most species with negative changepoints at both scales in both regions have well-known associations with intact habitats or landscapes, e.g., Common Loon, Swainson's Thrush. However, many species also had high uncertainty around identified change-points. For example, Blue Jay (Cyanocitta cristata) showed a weak change-point toward the end of the disturbance gradient in DMMB with confidence intervals spanning nearly its entire length and reliability levels at the lowest required by TITAN. This type of response may be indicative of a unimodal response to a disturbance gradient consistent with those seen under intermediate disturbance levels that are not well measured by TITAN (Baker and King 2010). Variable responses like this are not unexpected given that most species generally have different tolerances to changes in environmental conditions, the introduction of competitive species, and habitat isolation (Huggett 2005).

Similarly, response to changes in the surrounding landscape could be variable because different bird species use habitat at varying spatial scales and are therefore sensitive to different changes. For example, birds typically occurring in late seral stage forests are generally more sensitive to agricultural conversion than early successional and generalist species (Hobson and Bayne 2000, Hobson et al. 2000). Consistent with other studies, we found that most landbirds typical of contiguous forests such as Swainson's Thrush and Ovenbird responded negatively to increasing amounts of agriculture in the surrounding landscape (Hobson and Bayne 2000, Bayne and Hobson 2002). For these species, agricultural conversion resulted in permanent habitat loss due to forest removal.

In contrast, many waterbird species responded positively to increasing levels of agricultural conversion although most of these are species typically associated with more southern parkland and prairie habitats. Many factors in addition to landscape composition also affect suitability of wetlands and lakes for waterbirds including depth, area, nutrient concentrations, and food web structure (e.g., Paszkowski and Tonn 2000, Lemelin et al. 2010, Baschuk et al. 2012); however, these variables were 
beyond the scope of this study and likely exhibit complex interactions with our disturbance gradient. Breeding waterfowl densities are often greatest in shallow, productive, nutrient-rich wetlands and densities generally increase even along a more limited productivity gradient, i.e., eutrophic to hypereutrophic (Epners et al. 2010). Thus, waterbirds may have responded to increased food availability resulting from higher total dissolved phosphorous and subsequent productivity with greater fertilizer inputs (Epner et al. 2010) as the amount of area converted to agriculture increased (Hobson and Morissette, unpublished data). Further study is needed to establish whether these increases in abundance in fact represent an increase in habitat quality or whether they reflect a "crowding" response (increase in density) resulting from the loss of suitable wetlands in agricultural landscapes.

Predators such as corvids, gulls (Larus spp.), coyotes (Canis latrans), and skunks (Mephitis mephitis) are also typically more abundant in agricultural areas, which could potentially result in reduced nest success and increased mortality for waterfowl (Sargeant and Raveling 1992, Bayne and Hobson 1997). Exceptions in our study were Ring-necked Duck (Aythya collaris), Common Loon, and Red-necked Grebe (Podiceps grisegena), which declined in response to agricultural conversion. Common Loon are well known to be sensitive to human developments and our results reinforce the work of others that indicates vegetated buffers and minimal human disturbance are preferred by this species (Found et al. 2008). In effect, clearing and fragmenting boreal forest results in a superficial transition to more of a parkland or prairie landscape resulting in higher abundance of more open-country waterfowl into previously forested regions.

Species that inhabit the riparian ecotone showed variable responses to agricultural conversion. For example, Swamp Sparrow declined across scales in both study areas, but only showed a significant change-point in ECAB at the $500 \mathrm{~m}$ scale, i. e., around wetlands. White-throated Sparrow, a generalist species that also inhabits riparian zones, showed consistent declines in both regions although with no evidence of a change-point at the landscape-scale in ECAB. Colonial nesting Bonaparte's Gull (Chroicocephalus philadelphia), a species typical of boreal wetlands, also decreased with low amounts of agricultural conversion. Although declines of some riparian-associated species can be attributed to absolute wetland loss resulting from agricultural development (Guzy and Ritchison 1999), agricultural conversion in the landscape matrix may not impact some species that do not generally use forests adjacent to wetlands, e.g., Common Yellowthroat (Geothlypis trichas). Song Sparrow, Sora (Porzana carolina), and Red-winged Blackbird all showed increases in response to agriculture. Red-winged Blackbird may benefit from agricultural inputs, e.g., fertilizer, similar to waterbirds (Kirk et al. 2011) and did in fact respond positively to an increase in agriculture at both wetland- and landscape-scales in both study areas.

\section{Community-level responses to agricultural conversion}

Our analyses identified several areas along the disturbance gradient where synchronous changes in species composition occurred. As a result, the confidence intervals around community- level thresholds identified in TITAN tended to be large (Table 1). This result suggests that riparian- and wetland-associated bird communities did not typically exhibit a single threshold to agricultural conversion but rather community changes tended to occur throughout the full disturbance gradient. Nonetheless, several species exhibited synchronous change-points along the agricultural conversion gradient particularly at the landscapescale in ECAB. Baker and King (2010) noted that when anthropogenic disturbances result in positive responses within species assemblages, these may not represent well-organized communities. Instead, they may be composed of taxa that directly or indirectly benefit from resulting habitat changes, e.g., American Coot, related to resource subsidies or realized niche expansion, or to reduced competition or predation, respectively. Alternatively, these responses may be indicative of species not historically abundant in the boreal forest, e.g., Brown-headed Cowbird, but are able to cross ecosystem boundaries because of habitat changes resulting from anthropogenic disturbances (Baker and King 2010).

\section{Landscape-scale vs. wetland-scale effects}

Although most studies select research sites with the goal of assessing landscape context, we selected specific landscape settings to assess how gradients from intact boreal forest to those with high amounts of agricultural conversion affect bird communities. The advantage of this design is that variation between sites associated with habitat differences among wetlands is dampened (Radford et al. 2005). For example, changes appeared more gradual at the landscape scale than at the wetland scale as exemplified by typically wider confidence intervals and fewer significant indicator species (Fig. 2) illustrating direct impacts that may not be apparent at broader spatial scales. Ecological variability can also create uncertainty around change-point estimates and could obscure other threshold relationships in our data (e.g., Lindenmayer et al. 2005). We did not set out to test the effects of varying habitat configuration because we were explicitly testing changes in the landscape gradient around small openwater wetlands; however, such variation may have resulted in a lack of clear change-points in the avian community.

At the scale of an individual patch, transitions may appear abrupt because of the sudden loss of a key species (Chapin et al. 2004) while at a landscape-scale changes may appear more gradual on account of changes being distributed over space and time (Radford et al. 2005). For many species that exhibited negative responses to gradients in total disturbance in our study, thresholds were identified at relatively low levels of agricultural conversion, e.g., Red-breasted Nuthatch, Common Loon, or Mourning Warbler, still others did not show negative effects until more agricultural conversion had appeared. Variability in our landscapes related to permeability to different species (Machtans et al. 1996) could account for the inconsistencies in thresholds across scales and regions. For some bird species, the more traditional view of a landscape as a matrix of available and nonavailable habitat suggested by island biogeography (MacArthur and Wilson 1967) is not supported by the results of studies that have investigated their interaction with the landscape (Fahrig et al. 2011) or those with evidence for habitat compensation (Norton et al. 2000). 


\section{Regional responses to agricultural conversion}

Patterns in the occurrence of thresholds were generally different between our two study areas, particularly at the landscape-scale. For species that were common to both regions, direction of response was generally consistent, but change-points often differed. An exception was Bufflehead, a secondary cavity nester, which showed opposite responses in each region, increasing in DMMB and declining in ECAB. This pattern was consistent with that of primary cavity excavators, Northern Flicker (Colaptes auratus) and Yellow-bellied Sapsucker (Sphyrapicus varius; ECAB only). On the other hand, Mourning Warbler decreased in DMMB but not in ECAB with increasing agriculture. Finally, in ECAB thresholds generally occurred at higher levels of agricultural conversion than in DMMB.

There are a number of possible explanations for these differences between the two study areas. DMMB is an insular forest completely surrounded by agriculture and earlier change-points could reflect greater sensitivity to habitat loss due to greater distances to contiguous forest (Hobson and Bayne 2000) than in ECAB. Our study areas are separated by $\sim 750 \mathrm{~km}$ and bird species occurrence, richness, and abundance in the Boreal Plain generally declines with increasing latitude and decreasing longitude potentially resulting in innate differences between these regions (Sauer et al. 2017). Further, forest types are overall more variable in the ECAB study area, which generally has more lowland, e.g. bogs and fens, habitat across the landscape that are less susceptible to outright conversion to agriculture. Habitat loss can also lead to interactions between factors such as fragmentation and vegetation cover resulting in a range of thresholds (Huggett 2005). Smaller population sizes are also predicted to show lower tolerances to habitat loss (Swift and Hannon 2010) and regional populations in the insular DMMB are potentially smaller than areas more connected to relatively large expanses of forest (Brown 1984, Swift and Hannon 2010).

Long-term persistence of species within landscapes depends on maintaining breeding populations and our study addresses frequency of occurrence and relative abundances of species. Whether change-points are related to differing population trends in our two areas is potentially important and warrants further study. We did not explicitly test whether certain types of agriculture would result in earlier thresholds than others; however, in DMMB most farmland was planted to annual crops whereas in ECAB a mixture of areas cleared for grazing (tame pasture) and annual crops was present and these cover types may represent different levels of persistence for some species (Fahrig et al. 2011, Kirk et al. 2011).

\section{CONCLUSIONS}

Our study is the first to identify and compare changes in community composition of birds at wetlands along a gradient of agricultural conversion in two geographic regions of Canada's boreal transition zone. Theory around ecological thresholds developed using population-level simulation models, generally predicts extinction thresholds at $10-30 \%$ of habitat remaining (70-90\% conversion) on the landscape (Andrén 1994, Fahrig 2001). However, sensitivity of individual species to habitat fragmentation and landscape patterns can result in a much wider range (5-95\%) of habitat required for persistence (e.g., With and King 2001). We offer evidence that the abundance and frequency of occurrence of several species begins changing early along an agricultural disturbance gradient in the boreal forest. We consider these initiation of impact thresholds because the focus is on change rather than threshold per se, a point at which a stressor begins to negatively affect species, i.e., minimum detectable response; this approach could be used for implementing management plans before population-level changes occur (Hilderbrand et al. 2010). Therefore, these thresholds can be used to guide development in cases where growth is inevitable and the use of analytical methodologies such as TITAN help highlight species-level trade-offs of management decisions at the landscape scale. This is particularly true where thresholds may be used by decision makers as a conservation objective (Huggett 2005). As such, where conversion of forest to agriculture is unavoidable, limiting disturbance to $\sim 30 \%$ adjacent wetlands while retaining as much forest and wetland vegetation around wetlands may have the greatest benefit for the most species as shown in this and other studies (Darveau et al. 1995, Hannon et al. 2002, Kardynal et al. 2011). A similar disturbance limit within landscapes will also likely have substantial benefits for native boreal avifauna at that scale; however, understanding the configuration and extent of these disturbances that are of greatest conservation value requires additional research.

From a management perspective, the idea of finding a threshold where dramatic changes to ecological communities can be avoided is desirable. However, the large uncertainty, i.e., confidence intervals, associated with the community level change-points, suggests these values be interpreted with caution, with careful consideration to both species- and community-level changes that may be occurring. In addition, we demonstrate that threshold values identified using the same analytical technique vary as a function of geographic location and spatial scale. Our results lend weight to concerns shared by others that thresholds may be hard to generalize (Huggett 2005, Swift and Hannon 2010) and at this time have limited value for setting a precise point on a stressorresponse curve where further change will create a distinct change.

Does this mean we should stop searching for thresholds? No single study can confirm or deny the existence of thresholds. Thus, more work is needed to synthesize existing threshold analyses and/or combine datasets to allow broader testing of the threshold concept in a common analytical framework used across taxa and biomes. Regardless of whether a generalizable threshold is identified, the stressor-response type data collected for threshold studies are invaluable in helping managers evaluate if their population targets are being met. We argue that trying to find extinction thresholds is useful but we also need to worry about ensuring that targets of maintaining viable and self-sustaining populations of birds are met. For example, the North American Bird Conservation Initiative (Rich et al. 2004) has set out specific population goals for Bird Conservation Regions across North America. Collecting data to measure the size of bird populations along stressor gradients and changes in those stressor gradients is fundamental to understand if these targets are achieved.

The next 50 years are predicted to be the final expansion phase of modern agriculture (Tilman et al. 2001) and particularly in the southern Boreal Plain where the landscape is at risk of rapid 
conversion to agriculture (Hobson et al. 2002). Agricultural expansion not only leads to permanent conversion of forests but also results in substantial wetland loss (Slattery et al. 2011). Our results support other studies in upland boreal forest (Bayne and Hobson 1997) that suggest that to preserve boreal bird communities, policy changes that ensure forest cover is maintained and wetland loss minimized in the southern boreal mixedwood forest should be implemented.

Responses to this article can be read online at:

http://www.ace-eco.org/issues/responses.php/1355

\begin{abstract}
Acknowledgments:
We thank the Alberta Conservation Association (project \#0308090101), Sustainable Forest Management Network (project \# hobsonkbore9), Ducks Unlimited Canada (DUC), and Environment and Climate Change Canada (Western Boreal Conservation Initiative) and the University of Alberta for funding this project. C. Stevens, S. Smith, S. Bumstead, S. Haughian, L. Flaman, L. Stern, J. Burger, and D. Keeping provided valuable assistance in the field. GIS and programming support was provided by DUC, in particular M. Robin and S. Smyth. We also thank T. Cobb for helpful comments on earlier drafts of the manuscript.
\end{abstract}

\section{LITERATURE CITED}

Andrén, H. 1994. Effects of habitat fragmentation on birds and mammals in landscapes with different proportions of suitable habitat: a review. Oikos 71:355-366. http://dx.doi.org/10.2307/3545823

Baker, M. E., and R. S. King. 2010. A new method for detecting and interpreting biodiversity and ecological community thresholds. Methods in Ecology and Evolution 1:25-37. http://dx. doi.org/10.1111/j.2041-210X.2009.00007.x

Baker, M. E., and R. S. King. 2013. Of TITAN and straw men: an appeal for greater understanding of community data. Freshwater Science 32:489-506. http://dx.doi.org/10.1899/12-142.1

Baschuk, M. S., N. Koper, D. A. Wrubleski, and G. Goldsborough. 2012. Effects of water depth, cover and food resources on habitat use of marsh birds and waterfowl in boreal wetlands of Manitoba, Canada. Waterbirds 35:44-55. http://dx. doi.org/10.1675/063.035.0105

Bauer, D. M., P. W. Paton, and S. K. Swallow. 2010. Are wetland regulations cost effective for species protection? A case study of amphibian metapopulations. Ecological Applications 20:798-815. http://dx.doi.org/10.1890/08-2209.1

Bayley, S. E., A. S. Wong, and J. E. Thompson. 2013. Effects of agricultural encroachment and drought on wetlands and shallow lakes in the Boreal Transition zone of Canada. Wetlands 33:17-28. http://dx.doi.org/10.1007/s13157-012-0349-x

Bayne, E. M., and K. A. Hobson. 1997. Comparing the effects of landscape fragmentation by forestry and agriculture on predation of artificial nests. Conservation Biology 11:1418-1429. http://dx. doi.org/10.1046/j.1523-1739.1997.96135.x
Bayne, E. M., and K. A. Hobson. 2002. Apparent survival of male Ovenbirds in fragmented and forested boreal landscapes. Ecology 83:1307-1316. http://dx.doi.org/10.1890/0012-9658(2002) 083[1307:ASOMOI]2.0.CO;2

Bibby, C. J., N. D. Burgess, D. A. Hill, and S. Mustoe. 2000. Bird census techniques. Academic Press, London, UK.

Börger, L., and T. D. Nudds. 2014. Fire, humans, and climate: modeling distribution dynamics of boreal forest waterbirds Ecological Applications 24:121-141. http://dx.doi.org/10.1890/12-1683.1

Brown, J. H. 1984. On the relationship between abundance and distribution of species. American Naturalist 124:255-279. http:// dx.doi.org/10.1086/284267

Carlson, M., and F. Schmiegelow. 2002. Cost-effective sampling design applied to large-scale monitoring of boreal birds. Conservation Ecology 6(2):11. http://dx.doi.org/10.5751/ES-00438-060211

Chapin, F. S., T. V. Callaghan, Y. Bergeron, M. Fukuda, J. F. Johnstone, G. Juday, and S. A. Zimov. 2004. Global change and the boreal forest: thresholds, shifting states or gradual change? Ambio 33:361-365. http://dx.doi.org/10.1579/0044-7447-33.6.361

Conway, C. J. 2011. Standardized North American marsh bird monitoring protocol. Waterbirds 34:319-346. http://dx.doi. org/10.1675/063.034.0307

Croonquist, M. J., and R. P. Brooks. 1991. Use of avian and mammalian guilds as indicators of cumulative impacts in riparian-wetland areas Environmental Management 15:701-714. http://dx.doi.org/10.1007/BF02589628

Cuffney, T. F., and S. S. Qian. 2013. A critique of the use of indicator-species scores for identifying thresholds in species responses. Freshwater Science 32:471-488. http://dx.doi. org/10.1899/12-056.1

Cumming, E. E., K. A. Hobson, and S. L. Van Wilgenburg. 2001. Breeding bird declines in the boreal forest fringe of Western Canada: insights from long-term BBS routes. Canadian FieldNaturalist 115:425-435.

Darveau, M., P. Beauchesne, L. Bélanger, J. Huot, and P. Larue. 1995. Riparian forest strips as habitat for breeding birds in boreal forest. Journal of Wildlife Management 59:67-78. http://dx.doi. org/10.2307/3809117

De'ath, G., and K. E. Fabricius. 2000. Classification and regression trees: a powerful yet simple technique for ecological data analysis. Ecology 81:3178-3392. http://dx.doi.org/10.1890/0012-9658 (2000)081[3178:CARTAP]2.0.CO;2

DeMars, C. A., and S. Boutin. 2018. Nowhere to hide: effects of linear features on predator-prey dynamics in a large mammal system. Journal of Animal Ecology 87:274-284. http://dx.doi. org/10.1111/1365-2656.12760

Devictor, V., and A. Robert. 2009. Measuring community responses to large-scale disturbance in conservation biogeography. Diversity and Distributions 15:122-130. http://dx.doi.org/10.1111/ j.1472-4642.2008.00510.x

Dufrêne, M., and P. Legendre. 1997. Species assemblages and indicator species: the need for a flexible asymmetrical approach. Ecological Monographs 67:345-366. http://dx.doi.org/10.2307/2963459 
Ecological Stratification Working Group. 1996. A national ecological framework for Canada. Agriculture and Agri-Food Canada, Research Branch, Centre for Land and Biological Resources Research and State of the Environment Directorate, Environment Canada, Hull Québec, Canada.

Environment Canada. 2005. Narrative descriptions of terrestrial ecozones and ecoregions of Canada. Environment Canada, Hull Québec, Canada.

Epners, C. A., S. E. Bayley, J. E. Thompson, and W. M. Tonn. 2010. Influence of fish assemblage and shallow lake productivity on waterfowl communities in the Boreal Transition Zone of western Canada. Freshwater Biology 55:2265-2280. http://dx.doi. org/10.1111/j.1365-2427.2010.02432.X

Ervin, G., M. Smothers, C. Holly, C. Anderson, and J. Linville. 2006. Relative importance of wetland type versus anthropogenic activities in determining site invasibility. Biological Invasions 8:1425-1432. http://dx.doi.org/10.1007/s10530-006-0006-5

Fahrig, L. 2001. How much habitat is enough? Biological Conservation 100:65-74. http://dx.doi.org/10.1016/S0006-3207 (00)00208-1

Fahrig, L., J. Baudry, L. Brotons, F. G. Burel, T. O. Crist, R. J. Fuller, C. Sirami, G. M. Siriwardena, and J. L. Martin. 2011. Functional landscape heterogeneity and animal biodiversity in agricultural landscapes. Ecology Letters 14:101-112. http://dx. doi.org/10.1111/j.1461-0248.2010.01559.x

Foote, L., and N. Krogman. 2006. Wetlands in Canada's western boreal forest: agents of change. Forestry Chronicle 82:825-833. http://dx.doi.org/10.5558/tfc82825-6

Found, C., S. M. Webb, and M. S. Boyce. 2008. Selection of lake habitats by waterbirds in the boreal transition zone of northeastern Alberta. Canadian Journal of Zoology 86:277-285. http://dx.doi.org/10.1139/Z07-137

Gauthier, S., P. Bernier, T. Kuuluvainen, A. Z. Shvidenko, and D. G. Schepaschenko. 2015. Boreal forest health and global change. Science 349:819-822. http://dx.doi.org/10.1126/science.aaa9092

Groffman, P. M., J. S. Baron, T. Blett, A. J. Gold, I. Goodman, L. H. Gunderson, B. M. Levinson, M. A. Palmer, H. W. Paerl, G. D. Peterson, N. L. Poff, D. W. Rejeski, J. F. Reynolds, M. G. Turner, K. C. Weathers, and J. Wiens. 2006. Ecological thresholds: the key to successful environmental management or an important concept with no practical application? Ecosystems 9:1-13. http:// dx.doi.org/10.1007/s10021-003-0142-z

Guadagnin, D. L., and L. Maltchik. 2007. Habitat and landscape factors associated with neotropical waterbird occurrence and richness in wetland fragments. Biodiversity and Conservation 16:1231-1244. http://dx.doi.org/10.1007/s10531-006-9127-5

Guzy, M. J., and G. Ritchison. 1999. Common Yellowthroat (Geothlypis trichas), version 2.0. In A. F. Poole and F. B. Gill, editors. The birds of North America. Cornell Lab of Ornithology, Ithaca, New York, USA. https://doi.org/10.2173/bna.448

Haig, S. M., D. W. Mehlman, and L. W. Oring. 1998. Avian movements and wetland connectivity in landscape conservation. Conservation Biology 12:749-758. http://dx.doi.org/10.1111/ j.1523-1739.1998.97102.x
Hannon, S. J., and S. E. Cotterill. 1998. Nest predation in aspen woodlots in an agricultural area in Alberta: the enemy from within. Auk 115:16-25. http://dx.doi.org/10.2307/4089107

Hannon, S. J., C. A. Paszkowski, S. Boutin, J. DeGroot, S. E. Macdonald, M. Wheatley, and B. R. Eaton. 2002. Abundance and species composition of amphibians, small mammals, and songbirds in riparian forest buffer strips of varying widths in the boreal mixedwood of Alberta. Canadian Journal of Forest Research 32:1784-1800. http://dx.doi.org/10.1139/x02-092

Hansen, M. C., P. V. Potapov, R. Moore, M. Hancher, S. A. Turubanova, A. Tyukavina, D. Thau, S. V. Stehman, S. J. Goetz, T. R. Loveland, A. Kommareddy, A. Egorov, L. Chini, C. O. Justice, and J. R. Townshend. 2013. High-resolution global maps of 21st-century forest cover change. Science 342:850-853. http:// dx.doi.org/10.1126/science.1244693

Hilderbrand, R. H., R. M. Utz, S. A. Stranko, and R. L. Raesly. 2010. Applying thresholds to forecast potential biodiversity loss from human development. Journal of the North American Benthological Society 29:1009-1016. http://dx.doi.org/10.1899/09-138.1

Hobson, K. A., and E. M. Bayne. 2000. Effects of forest fragmentation by agriculture on avian communities in the southern boreal mixedwoods of western Canada. Wilson Bulletin 112:373-387. http://dx.doi.org/10.1676/0043-5643(2000)112[0373: EOFFBA]2.0.CO;2

Hobson, K. A., E. M. Bayne, and S. L. Van Wilgenburg. 2002. Large-scale conversion of forest to agriculture in the Boreal Plains of Saskatchewan. Conservation Biology 16:1530-1541. http://dx. doi.org/10.1046/j.1523-1739.2002.01199.x

Hobson, K. A., D. A. Kirk, and A. R. Smith. 2000. A multivariate analysis of breeding bird species of western and central Canadian boreal forests: stand and spatial effects 1. Ecoscience 7:267-280. http://dx.doi.org/10.1080/11956860.2000.11682596

Hoekstra, J. M., T. M. Boucher, T. H. Ricketts, and C. Roberts. 2004. Confronting a biome crisis: global disparities of habitat loss and protection. Ecology Letters 8:23-29. http://dx.doi. org/10.1111/j.1461-0248.2004.00686.x

Houlahan, J. E., and C. S. Findlay. 2004. Estimating the 'critical' distance at which adjacent land-use degrades wetland water and sediment quality. Landscape Ecology 19:677-690. http://dx.doi. org/10.1023/B:LAND.0000042912.87067.35

Houlahan, J. E., P. A. Keddy, K. Makkay, and C. S. Findlay. 2006. The effects of adjacent land use on wetland species richness and community composition. Wetlands 26:79-96. http://dx.doi. org/10.1672/0277-5212(2006)26[79:TEOALU]2.0.CO;2

Huggett, A. J. 2005. The concept and utility of 'ecological thresholds' in biodiversity conservation. Biological Conservation 124:301-310. http://dx.doi.org/10.1016/j.biocon.2005.01.037

Kardynal, K. J., J. L. Morissette, S. L. Van Wilgenburg, E. M. Bayne, and K. A. Hobson. 2011. Avian responses to experimental harvest in southern boreal mixedwood shoreline forests: implications for riparian buffer management. Canadian Journal of Forest Research 41:2375-2388. http://dx.doi.org/10.1139/ $\mathrm{x} 11-145$ 
Avian Conservation and Ecology 14(1): 12

Kennedy, C. M., E. H. C. Grant, M. C. Neel, W. F. Fagan, and P. P. Marra. 2011. Landscape matrix mediates occupancy dynamics of Neotropical avian insectivores. Ecological Applications 21:1837-1850. http://dx.doi.org/10.1890/10-1044.1

Kirk, D. A., K. E. Lindsay, and R. W. Brook. 2011. Risk of agricultural practices and habitat change to farmland birds. Avian Conservation and Ecology 6(1):5. http://dx.doi.org/10.5751/ ACE-00446-060105

Larsen, S., A. Sorace, and L. Mancini. 2010. Riparian bird communities as indicators of human impacts along Mediterranean streams. Environmental Management 45:261-273. http://dx.doi.org/10.1007/s00267-009-9419-0

Lemelin, L.-V., M. Darveau, L. Imbeau, and D. Bordage. 2010. Wetland use and selection by breeding waterbirds in the boreal forest of Quebec, Canada. Wetlands 30:321-332. http://dx.doi. org/10.1007/s13157-010-0024-Z

Lepczyk, C. A., C. H. Flather, V. C. Radeloff, A. M. Pidgeon, R. B. Hammer, and J. Liu. 2008. Human impacts on regional avian diversity and abundance. Conservation Biology 22:405-416. http:// dx.doi.org/10.1111/j.1523-1739.2008.00881.x

Lindenmayer, D. B., J. Fischer, and R. B. Cunningham. 2005. Native vegetation cover thresholds associated with species responses. Biological Conservation 124:311-316. http://dx.doi. org/10.1016/j.biocon.2005.01.038

Locky, D. A., S. E. Bayley, and D. H. Vitt. 2005. The vegetational ecology of black spruce swamps, fens, and bogs in southern boreal Manitoba, Canada. Wetlands 25:564-582. http://dx.doi. org/10.1672/0277-5212(2005)025[0564:TVEOBS]2.0.CO;2

Lougheed, V. L., M. D. McIntosh, C. A. Parker, and R. J. Stevenson. 2008. Wetland degradation leads to homogenization of the biota at local and landscape scales. Freshwater Biology 53:2402-2413. http://dx.doi.org/10.1111/j.1365-2427.2008.02064. $\mathrm{x}$

Louisiana Pacific Canada Ltd. 1995. Ten year forest management plan (1996-2005). Louisiana Pacific Canada Ltd., Swan River, Manitoba, Canada.

MacArthur, R. H., and E. O. Wilson. 1967. The theory of island biogeography. Princeton University Press, Princeton, New Jersey, USA. http://dx.doi.org/10.1515/9781400881376

Machtans, C. S., M.-A. Villard, and S. J. Hannon. 1996. Use of riparian buffer strips as movement corridors by forest birds. Conservation Biology 10:1366-1379. http://dx.doi.org/10.1046/ j.1523-1739.1996.10051366.x

Manly, B. F. J. 1997. Randomization, bootstrap and Monte Carlo methods in biology. Second edition. Chapman and Hall, London, UK.

McCune, B., and J. B. Grace. 2002. Analysis of ecological communities. MjM Sofware Design, Gleneden Beach, Oregon, USA.

Norton, M. R., S. J. Hannon, and F. K. A. Schmiegelow. 2000. Fragments are not islands: patch vs landscape perspectives on songbird presence and abundance in a harvested boreal forest.
Ecography 23:209-223. http://dx.doi.org/10.1111/j.1600-0587.2000. tb00277.x

Paszkowski, C. A., and W. M. Tonn. 2000. Community concordance between the fish and aquatic birds of lakes in northern Alberta, Canada: the relative importance of environmental and biotic factors. Freshwater Biology 43:421-437. http://dx.doi.org/10.1046/j.1365-2427.2000.00512.x

Pereira, H. M., L. M. Navarro, and I. S. Martins. 2012. Global biodiversity change: the bad, the good, and the unknown. Annual Review of Environment and Resources 37:25-50. http://dx.doi. org/10.1146/annurev-environ-042911-093511

Perrings, C., and G. Halkos. 2015. Agriculture and the threat to biodiversity in sub-Saharan Africa. Environmental Research Letters 10:095015. http://dx.doi.org/10.1088/1748-9326/10/9/095015

Petrone, R. M., U. Silins, and K. J. Devito. 2007. Dynamics of evapotranspiration from a riparian pond complex in the Western Boreal Forest, Alberta, Canada. Hydrological Processes 21:1391-1401. http://dx.doi.org/10.1002/hyp.6298

Radford, J. Q., A. F. Bennett, and G. J. Cheers. 2005. Landscapelevel thresholds of habitat cover for woodland-dependent birds. Biological Conservation 124:317-337. http://dx.doi.org/10.1016/j. biocon.2005.01.039

Ramankutty, N., J. A. Foley, J. Norman, and K. McSweeney. 2002. The global distribution of cultivable lands: current patterns and sensitivity to possible climate change. Global Ecology and Biogeography 11:377-392. http://dx.doi.org/10.1046/ j.1466-822x.2002.00294.x

Rich, T. D., C. J. Beardmore, H. Berlanga, P. J. Blancher, M. S. W. Bradstreet, G. S. Butcher, D. W. Demarest, E. H. Dunn, W. C. Hunter, E. E. Iñigo-Elias, J. A. Kennedy, A. M. Martell, A. O. Panjabi, D. N. Pashley, K. V. Rosenberg, C. M. Rustay, J. S. Wendt, and T. C. Will. 2004. Partners in Flight North American Landbird Conservation Plan. Cornell Lab of Ornithology, Ithaca, New Yorl, USA. [online] URL: http://www.partnersinflight.org/wp-content/ uploads/2016/07/PIF-Landbird-Conservation-Plan-2004.pdf

Rodewald, A. D., and M. H. Bakermans. 2006. What is the appropriate paradigm for riparian forest conservation? Biological Conservation 128:193-200. http://dx.doi.org/10.1016/j.biocon.2005.09.041

Rooney, R. C., and S. E. Bayley. 2011. Relative influence of localand landscape-level habitat quality on aquatic plant diversity in shallow open-water wetlands in Alberta's boreal zone: direct and indirect effects. Landscape Ecology 26:1023-1034. http://dx.doi. org/10.1007/s10980-011-9629-8

Saab, V. 1999. Importance of spatial scale to habitat use by breeding birds in riparian forests: a hierarchical analysis. Ecological Applications 9:135-151. http://dx.doi.org/10.1890/1051-0761 (1999)009[0135:IOSSTH]2.0.CO;2

Sargeant, A. B., and D. G. Raveling. 1992. Mortality during the breeding season. University of Minnesota Press, Minneapolis, Minnesota, USA.

Sauer, J. R., D. K. Niven, J. E. Hines, D. J. Ziolkowski, K. L. Pardieck, J. E. Fallon, and W. A. Link. 2017. The North American breeding bird survey, results and analysis 1966-2015. Version 
2.07.2017. USGS Patuxent Wildlife Research Center, editor, Laurel, Maryland, USA.

Shea, K., S. H. Roxburgh, and E. S. J. Rauschert. 2004. Moving from pattern to process: coexistence mechanisms under intermediate disturbance regimes. Ecology Letters 7:491-508. http://dx.doi.org/10.1111/j.1461-0248.2004.00600.x

Slattery, S. M., J. L. Morissette, G. G. Mack, and E. W. Butterworth. 2011. Waterfowl conservation planning: science needs and approaches. Pages 23-40 in J. V. Wells editor. Boreal birds of North America: a hemispheric view of their conservation links and significance. University of California Press, Berkeley, California, USA.

Swift, T. L., and S. J. Hannon. 2010. Critical thresholds associated with habitat loss: a review of the concepts, evidence, and applications. Biological Reviews 85:35-53. http://dx.doi. org/10.1111/j.1469-185X.2009.00093.X

Tarnocai, C. 2009. The impact of climate change on Canadian peatlands. Canadian Water Resources Journal 34:453-466. http:// dx.doi.org/10.4296/cwrj3404453

Tilman, D., J. Fargione, B. Wolff, C. D'Antonio, A. Dobson, R. Howarth, D. Schindler, W. H. Schlesinger, D. Simberloff, and D. Swackhamer. 2001. Forecasting agriculturally driven global environmental change. Science 292:281-284. http://dx.doi. org/10.1126/science.1057544

Trettin, C. C., M. F. Jurgensen, D. F. Grigal, M. R. Gale, and J. R. Jeglum. 1996. Northern forested wetlands: ecology and management. CRC Press, New York, New York, USA. http://dx. doi.org/10.1201/9780203745380

Tsai, J.-S., L. S. Venne, S. T. McMurry, and L. M. Smith. 2012. Local and landscape influences on plant communities in playa wetlands. Journal of Applied Ecology 49:174-181. http://dx.doi. org/10.1111/j.1365-2664.2011.02063.X

Venier, L. A., I. D. Thompson, R. Fleming, J. Malcolm, I. Aubin, J. A. Trofymow, D. Langor, R. Sturrock, C. Patry, R. O. Outerbridge, S. B. Holmes, S. Haeussler, L. De Grandpré, H. Y. H. Chen, E. Bayne, A. Arsenault, and J. P. Brandt. 2014. Effects of natural resource development on the terrestrial biodiversity of Canadian boreal forests1. Environmental Reviews 22:457-490. http://dx.doi.org/10.1139/er-2013-0075

Vitt, D. H., L. Halsey, and S. C. Zoltai. 1994. The bog landforms of continental western Canada in relation to climate and permafrost patterns. Arctic and Alpine Research 26:1-13. http:// dx.doi.org/10.2307/1551870

Whitehouse, H. E., and S. E. Bayley. 2005. Vegetation patterns and biodiversity of peatland plant communities surrounding midboreal wetland ponds in Alberta, Canada. Canadian Journal of Botany 83:621-637. http://dx.doi.org/10.1139/b05-034
Wilcove, D. S., X. Giam, D. P. Edwards, B. Fisher, and L. Pin Koh. 2013. Navjot's nightmare revisited: logging, agriculture, and biodiversity in Southeast Asia. Trends in Ecology \& Evolution 28:531-540. http://dx.doi.org/10.1016/j.tree.2013.04.005

With, K. A., and A. W. King. 2001. Analysis of landscape sources and sinks: the effect of spatial pattern on avian demography. Biological Conservation 100:75-88. http://dx.doi.org/10.1016/ S0006-3207(00)00209-3

Zabel, F., B. Putzenlechner, and W. Mauser. 2014. Global agricultural land resources - a high resolution suitability evaluation and its perspectives until 2100 under climate change conditions. PLoS ONE 9:e107522. http://dx.doi.org/10.1371/ journal.pone.0107522

Zhang, X., and X. Cai. 2011. Climate change impacts on global agricultural land availability. Environmental Research Letters 6:014014. http://dx.doi.org/10.1088/1748-9326/6/1/014014
Editor-in-Chief: Ryan Norris Subject Editor: Wayne E.Thogmartin
Sponsored by the Society of Canadian Ornithologists and Bird Studies Canada Parrainée par la Société des ornithologistes $d u$ Canada et Études d'oiseaux Canada

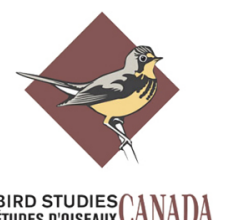


Table A1.1. Individual species results from TITAN from bird surveys conducted in the east-central Alberta (ECAB) study area. Species codes, common names, scientific names, indicator scores (IndVal), change-points (Cp) and percentiles (5\%, 50\%, 95\%), for declining (-) and increasing taxa $(+)$ in response to agricultural conversion at the $(\mathrm{A})$ wetland $(500 \mathrm{~m})$ and landscape (B) scales. Note that all significant indicator species are shown but that only species that met significance criteria for $P(\leq 0.05)$, purity $(\geq 0.95)$, and reliability $(\geq 0.95$, and $\geq$ 0.9 for at 0.05 , and 0.01 , respectively) are included in the figures. $\mathrm{P}$ is the probability of getting an equal or larger IndVal using 250 random permutations. IndVal is the unstandardized indicator score, $\mathrm{z}$ is the standardized indicator value and $\mathrm{N}$ is the frequency of species occurrence among landscapes/wetlands sampled.

\begin{tabular}{|c|c|c|c|c|c|c|c|c|c|c|c|c|c|c|}
\hline \multicolumn{15}{|c|}{ A1.1A. Wetland-scale } \\
\hline Code & Common Name & Scientific Name & "+/-" & $\mathrm{Cp}$ & $5 \%$ & $50 \%$ & $95 \%$ & $\mathrm{Z}$ & IndVal & $\mathrm{P}$ & Purity & rel05 & rel01 & $\mathrm{N}$ \\
\hline ALFL & Alder Flycatcher & Empidonax alnorum & - & 0.78 & 0.13 & 0.60 & 0.83 & 2.25 & 35.89 & 0.04 & 0.91 & 0.84 & 0.50 & 41 \\
\hline $\mathrm{BOCH}$ & Boreal Chickadee & Poecile hudsonicus & - & 0.13 & 0.03 & 0.12 & 0.15 & 7.22 & 22.73 & 0.00 & 1.00 & 0.97 & 0.82 & 5 \\
\hline BOGU & Bonaparte's Gull & Larus philadelphia & - & 0.41 & 0.03 & 0.34 & 0.52 & 3.72 & 19.53 & 0.01 & 1.00 & 0.95 & 0.72 & 13 \\
\hline CHSP & Chipping Sparrow & Spizella passerina & - & 0.65 & 0.08 & 0.19 & 0.73 & 2.85 & 28.37 & 0.02 & 0.97 & 0.89 & 0.54 & 26 \\
\hline COLO & Common Loon & Gavia immer & - & 0.11 & 0.06 & 0.12 & 0.30 & 8.48 & 57.83 & 0.00 & 1.00 & 1.00 & 1.00 & 29 \\
\hline CONW & Connecticut Warbler & Oporornis agilis & - & 0.35 & 0.15 & 0.34 & 0.42 & 4.18 & 22.20 & 0.00 & 0.93 & 0.91 & 0.78 & 16 \\
\hline GRAJ & Gray Jay & Perisoreus canadensis & - & 0.06 & 0.03 & 0.07 & 0.29 & 6.93 & 27.03 & 0.01 & 1.00 & 0.94 & 0.77 & 6 \\
\hline HETH & Hermit Thrush & Catharus guttatus & - & 0.42 & 0.11 & 0.37 & 0.51 & 6.66 & 37.58 & 0.00 & 1.00 & 1.00 & 0.98 & 27 \\
\hline LCSP & Le Conte's Sparrow & Ammodramus leconteii & - & 0.21 & 0.12 & 0.27 & 0.91 & 3.64 & 31.04 & 0.01 & 0.81 & 0.76 & 0.61 & 29 \\
\hline LISP & $\begin{array}{l}\text { Lincoln's Sparrow } \\
\text { Yellow-rumped }\end{array}$ & Melospiza lincolnii & - & 0.58 & 0.10 & 0.53 & 0.83 & 3.11 & & 0.02 & 1.00 & 0.95 & 0.72 & 45 \\
\hline YRWA & Warbler & Setophaga coronata & - & 0.19 & 0.05 & 0.24 & 0.87 & 2.92 & 38.46 & 0.02 & 0.88 & 0.84 & 0.63 & 47 \\
\hline NOFL & Northern Flicker & Colaptes auratus & - & 0.34 & 0.09 & 0.31 & 0.87 & 1.97 & 8.96 & 0.02 & 0.77 & 0.49 & 0.26 & 6 \\
\hline OVEN & $\begin{array}{l}\text { Ovenbird } \\
\text { Rose-breasted }\end{array}$ & $\begin{array}{l}\text { Seiurus aurocapillus } \\
\text { Pheucticus }\end{array}$ & - & 0.21 & 0.13 & 0.27 & 0.56 & 7.14 & 42.53 & 0.00 & 1.00 & 1.00 & 0.99 & 28 \\
\hline RBGR & Grosbeak & ludovicianus & - & 0.45 & 0.13 & 0.42 & 0.54 & 4.51 & 20.63 & 0.00 & 1.00 & 0.97 & 0.86 & 13 \\
\hline RCKI & Ruby-crowned Kinglet & Regulus calendula & - & 0.47 & 0.15 & 0.54 & 0.76 & 4.21 & 30.51 & 0.00 & 1.00 & 1.00 & 0.83 & 29 \\
\hline RNDU & Ring-necked Duck & Aythya collaris & - & 0.10 & 0.07 & 0.35 & 0.64 & 3.92 & 50.11 & 0.00 & 1.00 & 0.99 & 0.87 & 42 \\
\hline RNGR & Red-necked Grebe & Podiceps grisegena & - & 0.64 & 0.36 & 0.62 & 0.73 & 5.17 & 45.77 & 0.00 & 0.97 & 0.97 & 0.91 & 40 \\
\hline SACR & Sandhill Crane & Grus canadensis & - & 0.11 & 0.04 & 0.11 & 0.30 & 4.70 & 20.50 & 0.00 & 1.00 & 0.88 & 0.67 & 6 \\
\hline DEJU & Dark-eyed Junco & Junco hyemalis & - & 0.34 & 0.17 & 0.31 & 0.47 & 7.28 & 40.20 & 0.00 & 1.00 & 1.00 & 1.00 & 31 \\
\hline SWSP & Swamp Sparrow & Melospiza georgiana & - & 0.10 & 0.06 & 0.24 & 0.64 & 2.82 & 35.42 & 0.03 & 0.95 & 0.90 & 0.66 & 29 \\
\hline SWTH & Swainson's Thrush & Catharus ustulatus & - & 0.30 & 0.13 & 0.31 & 0.47 & 5.87 & 27.44 & 0.00 & 0.97 & 0.97 & 0.95 & 17 \\
\hline TEWA & Tennessee Warbler & Oreothlypis peregrina & - & 0.35 & 0.12 & 0.36 & 0.68 & 4.73 & 34.57 & 0.00 & 0.95 & 0.94 & 0.83 & 31 \\
\hline
\end{tabular}




\begin{tabular}{|c|c|c|c|c|c|c|c|c|c|c|c|c|c|}
\hline WPWA & $\begin{array}{l}\text { Palm Warbler } \\
\text { White-throated }\end{array}$ & Setophaga palmarum & - & 0.03 & 0.03 & 0.20 & 0.38 & 4.11 & 33.22 & 0.03 & 0.99 & 0.92 & 0.79 \\
\hline WTSP & $\begin{array}{l}\text { Sparrow } \\
\text { Yellow-bellied }\end{array}$ & Zonotrichia albicollis & - & 0.34 & 0.03 & 0.34 & 0.69 & 5.38 & 52.71 & 0.00 & 0.99 & 0.99 & 0.89 \\
\hline YBSA & Sapsucker & Sphyrapicus varius & - & 0.05 & 0.03 & 0.06 & 0.87 & 4.32 & 27.88 & 0.02 & 0.86 & 0.63 & 0.40 \\
\hline AGWT & Green-winged Teal & Anas crecca & + & 0.69 & 0.03 & 0.54 & 0.81 & 2.03 & 16.37 & 0.03 & 0.69 & 0.55 & 0.32 \\
\hline AMCO & American Coot & $\begin{array}{l}\text { Fulica americana } \\
\text { Corvus }\end{array}$ & + & 0.15 & 0.12 & 0.30 & 0.56 & 4.90 & 43.49 & 0.01 & 1.00 & 1.00 & 0.96 \\
\hline AMCR & American Crow & brachyrhynchos & + & 0.89 & 0.27 & 0.73 & 0.91 & 5.58 & 65.21 & 0.01 & 0.98 & 0.96 & 0.79 \\
\hline BAOR & Baltimore Oriole & Icterus galbula & + & 0.47 & 0.22 & 0.50 & 0.73 & 4.38 & 16.97 & 0.01 & 1.00 & 0.94 & 0.67 \\
\hline BBMA & $\begin{array}{l}\text { Black-billed Magpie } \\
\text { Brown-headed }\end{array}$ & Pica pica & + & 0.67 & 0.41 & 0.64 & 0.87 & 4.45 & 21.32 & 0.00 & 0.95 & 0.89 & 0.75 \\
\hline $\mathrm{BHCO}$ & Cowbird & Molothrus ater & + & 0.14 & 0.14 & 0.34 & 0.83 & 3.78 & 25.00 & 0.00 & 1.00 & 1.00 & 0.79 \\
\hline BWTE & Blue-winged Teal & Anas discors & + & 0.55 & 0.22 & 0.48 & 0.62 & 6.34 & 56.66 & 0.00 & 1.00 & 0.98 & 0.95 \\
\hline CCSP & Clay-colored Sparrow & Spizella pallida & + & 0.55 & 0.12 & 0.56 & 0.79 & 3.80 & 42.57 & 0.00 & 0.99 & 0.97 & 0.74 \\
\hline EAGR & Eared Grebe & Podiceps nigricollis & + & 0.60 & 0.52 & 0.62 & 0.83 & 4.62 & 12.00 & 0.02 & 0.96 & 0.74 & 0.52 \\
\hline GADW & Gadwall & Anas strepera & + & 0.76 & 0.03 & 0.67 & 0.84 & 3.47 & 15.15 & 0.03 & 0.67 & 0.52 & 0.35 \\
\hline HOWR & House Wren & Troglodytes aedon & + & 0.55 & 0.23 & 0.55 & 0.83 & 3.33 & 13.91 & 0.01 & 1.00 & 0.88 & 0.56 \\
\hline KILL & Killdeer & Charadrius vociferus & + & 0.56 & 0.15 & 0.54 & 0.81 & 4.36 & 26.27 & 0.00 & 0.94 & 0.91 & 0.72 \\
\hline LEFL & Least Flycatcher & Empidonax minimus & + & 0.30 & 0.06 & 0.29 & 0.88 & 2.32 & 27.81 & 0.05 & 0.79 & 0.68 & 0.39 \\
\hline MALL & Mallard & $\begin{array}{l}\text { Anas platyrhynchos } \\
\text { Oporornis }\end{array}$ & + & 0.14 & 0.04 & 0.15 & 0.86 & 2.15 & 39.91 & 0.04 & 0.98 & 0.86 & 0.46 \\
\hline MOWA & Mourning Warbler & philadelphia & + & 0.73 & 0.29 & 0.69 & 0.91 & 3.60 & 17.51 & 0.02 & 0.96 & 0.86 & 0.55 \\
\hline NOPI & Northern Pintail & Anas acuta & + & 0.55 & 0.17 & 0.54 & 0.78 & 2.76 & 11.24 & 0.01 & 0.87 & 0.51 & 0.25 \\
\hline NSHO & Northern Shoveler & Anas clypeata & + & 0.54 & 0.33 & 0.52 & 0.60 & 7.79 & 45.82 & 0.00 & 1.00 & 1.00 & 0.96 \\
\hline NSTS & Nelson's Sparrow & Ammodramus nelsoni & + & 0.30 & 0.21 & 0.31 & 0.57 & 2.24 & 8.77 & 0.05 & 0.91 & 0.43 & 0.18 \\
\hline PBGR & Pied-billed Grebe & Podilymbus podiceps & + & 0.51 & 0.09 & 0.47 & 0.91 & 3.25 & 25.87 & 0.01 & 0.91 & 0.84 & 0.58 \\
\hline RBNU & Red-breasted Nuthatch & Sitta canadensis & + & 0.35 & 0.14 & 0.38 & 0.56 & 1.61 & 8.59 & 0.04 & 0.80 & 0.48 & 0.23 \\
\hline REDH & Redhead & Aythya americana & + & 0.55 & 0.17 & 0.52 & 0.65 & 5.91 & 33.02 & 0.00 & 0.99 & 0.98 & 0.90 \\
\hline REVI & Red-eyed Vireo & Vireo olivaceus & + & 0.13 & 0.11 & 0.16 & 0.88 & 2.06 & 35.88 & 0.04 & 0.73 & 0.58 & 0.33 \\
\hline RUDU & Ruddy Duck & Oxyura jamaicensis & + & 0.36 & 0.13 & 0.37 & 0.52 & 6.50 & 38.98 & 0.00 & 1.00 & 1.00 & 1.00 \\
\hline RWBL & Red-winged Blackbird & $\begin{array}{l}\text { Agelaius phoeniceus } \\
\text { Passerculus }\end{array}$ & + & 0.38 & 0.23 & 0.36 & 0.43 & 10.54 & 67.10 & 0.00 & 1.00 & 1.00 & 1.00 \\
\hline SAVS & Savannah Sparrow & sandwichensis & + & 0.65 & 0.25 & 0.54 & 0.69 & 7.96 & 45.15 & 0.00 & 1.00 & 1.00 & 1.00 \\
\hline SORA & Sora & Porzana carolina & + & 0.35 & 0.07 & 0.33 & 0.47 & 4.64 & 52.68 & 0.00 & 1.00 & 1.00 & 0.91 \\
\hline
\end{tabular}




\begin{tabular}{|c|c|c|c|c|c|c|c|c|c|c|c|c|c|c|}
\hline SOSA & Solitary Sandpiper & Tringa solitaria & + & 0.89 & 0.21 & 0.88 & 0.91 & 3.84 & 42.99 & 0.04 & 0.88 & 0.65 & 0.40 & 8 \\
\hline SOSP & Song Sparrow & Melospiza melodia & + & 0.69 & 0.21 & 0.56 & 0.81 & 9.35 & 67.42 & 0.00 & 1.00 & 1.00 & 1.00 & 42 \\
\hline VESP & $\begin{array}{l}\text { Vesper Sparrow } \\
\text { Yellow-headed }\end{array}$ & $\begin{array}{l}\text { Pooecetes gramineus } \\
\text { Xanthocephalus }\end{array}$ & + & 0.76 & 0.42 & 0.67 & 0.81 & 10.38 & 45.70 & 0.00 & 1.00 & 1.00 & 0.99 & 13 \\
\hline YHBL & Blackbird & xanthocephalus & + & 0.45 & 0.42 & 0.49 & 0.67 & 5.88 & 18.92 & 0.00 & 1.00 & 0.99 & 0.89 & 7 \\
\hline YEWA & Yellow Warbler & Setophaga petechia & + & 0.30 & 0.10 & 0.29 & 0.57 & 4.72 & 42.96 & 0.00 & 1.00 & 0.98 & 0.86 & 44 \\
\hline
\end{tabular}

\begin{tabular}{|c|c|c|c|c|c|c|c|c|c|c|c|c|c|c|}
\hline \multicolumn{15}{|c|}{ A1.1B. Landscape-scale } \\
\hline Code & Common Name & Scientific Name & Response & $\mathrm{Cp}$ & $5 \%$ & $50 \%$ & $95 \%$ & $\mathrm{z}$ & IndVal & $\mathrm{p}$ & Purity & rel05 & rel01 & $\mathrm{N}$ \\
\hline BUFF & Bufflehead & Bucephala albeola & - & 0.19 & 0.14 & 0.51 & 0.72 & 2.70 & 67.50 & 0.02 & 0.99 & 0.96 & 0.61 & 17 \\
\hline CHSP & Chipping Sparrow & Spizella passerina & - & 0.29 & 0.19 & 0.28 & 0.66 & 3.17 & 67.91 & 0.01 & 1.00 & 0.94 & 0.68 & 18 \\
\hline COLO & Common Loon & Gavia immer & - & 0.51 & 0.22 & 0.54 & 0.72 & 3.83 & 68.28 & 0.00 & 0.99 & 0.95 & 0.75 & 16 \\
\hline CONW & Connecticut Warbler & Oporornis agilis & - & 0.28 & 0.14 & 0.28 & 0.56 & 2.36 & 55.44 & 0.03 & 0.99 & 0.92 & 0.52 & 13 \\
\hline GRAJ & Gray Jay & Perisoreus canadensis & - & 0.28 & 0.16 & 0.27 & 0.53 & 4.50 & 59.20 & 0.00 & 1.00 & 0.92 & 0.69 & 8 \\
\hline GRYE & Greater Yellowlegs & Tringa melanoleuca & - & 0.26 & 0.14 & 0.25 & 0.37 & 4.17 & 44.44 & 0.01 & 1.00 & 0.78 & 0.48 & 4 \\
\hline HETH & Hermit Thrush & $\begin{array}{l}\text { Catharus guttatus } \\
\text { Ammodramus }\end{array}$ & - & 0.72 & 0.16 & 0.54 & 0.72 & 2.37 & 77.27 & 0.03 & 0.87 & 0.78 & 0.52 & 17 \\
\hline LCSP & Le Conte's Sparrow & leconteii & - & 0.23 & 0.14 & 0.26 & 0.60 & 3.18 & 68.48 & 0.01 & 0.94 & 0.88 & 0.59 & 17 \\
\hline LEYE & $\begin{array}{l}\text { Lesser Yellowlegs } \\
\text { Yellow-rumped }\end{array}$ & Tringa flavipes & - & 0.16 & 0.14 & 0.19 & 0.70 & 5.53 & 81.65 & 0.00 & 0.86 & 0.78 & 0.61 & 10 \\
\hline YRWA & Warbler & Setophaga coronata & - & 0.19 & 0.14 & 0.46 & 0.70 & 2.06 & 59.11 & 0.02 & 0.89 & 0.70 & 0.33 & 23 \\
\hline NOFL & Northern Flicker & Colaptes auratus & - & 0.29 & 0.14 & 0.28 & 0.57 & 3.42 & 52.51 & 0.02 & 0.91 & 0.82 & 0.51 & 8 \\
\hline OVEN & $\begin{array}{l}\text { Ovenbird } \\
\text { Rose-breasted }\end{array}$ & $\begin{array}{l}\text { Seiurus aurocapillus } \\
\text { Pheucticus }\end{array}$ & - & 0.51 & 0.28 & 0.51 & 0.70 & 5.58 & 81.66 & 0.00 & 1.00 & 1.00 & 0.97 & 16 \\
\hline RBGR & Grosbeak & ludovicianus & - & 0.46 & 0.19 & 0.51 & 0.70 & 3.96 & 66.82 & 0.00 & 0.98 & 0.96 & 0.84 & 16 \\
\hline RCKI & Ruby-crowned Kinglet & Regulus calendula & - & 0.53 & 0.16 & 0.54 & 0.72 & 3.65 & 65.49 & 0.01 & 0.96 & 0.85 & 0.64 & 17 \\
\hline RNDU & Ring-necked Duck & Aythya collaris & - & 0.72 & 0.16 & 0.66 & 0.72 & 2.79 & 70.84 & 0.01 & 0.93 & 0.83 & 0.58 & 23 \\
\hline SACR & Sandhill Crane & Grus canadensis & - & 0.46 & 0.26 & 0.36 & 0.53 & 2.32 & 35.71 & 0.02 & 0.89 & 0.51 & 0.22 & 5 \\
\hline DEJU & Dark-eyed Junco & Junco hyemalis & - & 0.53 & 0.29 & 0.53 & 0.60 & 6.39 & 88.43 & 0.00 & 1.00 & 0.99 & 0.99 & 18 \\
\hline SWSP & Swamp Sparrow & Melospiza georgiana & - & 0.72 & 0.14 & 0.50 & 0.72 & 1.65 & 68.01 & 0.02 & 0.78 & 0.62 & 0.41 & 19 \\
\hline SWTH & Swainson's Thrush & Catharus ustulatus & - & 0.54 & 0.29 & 0.53 & 0.66 & 4.52 & 70.59 & 0.00 & 0.98 & 0.95 & 0.66 & 12 \\
\hline TEWA & Tennessee Warbler & Vermivora peregrina & - & 0.54 & 0.23 & 0.46 & 0.70 & 3.85 & 73.23 & 0.01 & 1.00 & 1.00 & 0.90 & 19 \\
\hline WETA & Western Tanager & Piranga ludoviciana & - & 0.28 & 0.16 & 0.27 & 0.46 & 3.00 & 36.36 & 0.04 & 0.98 & 0.63 & 0.40 & 4 \\
\hline PAWA & Palm Warbler & Setophaga palmarum & - & 0.51 & 0.14 & 0.36 & 0.66 & 2.29 & 49.36 & 0.03 & 0.96 & 0.78 & 0.45 & 10 \\
\hline
\end{tabular}


White-throated

\begin{tabular}{|c|c|c|}
\hline WTSP & Sparrow & Zonotrichia albicollis \\
\hline AGWT & Green-winged Teal & Anas crecca \\
\hline AMCO & American Coot & Fulica americana \\
\hline AMRO & $\begin{array}{l}\text { American Robin } \\
\text { Black-and-white }\end{array}$ & Turdus migratorius \\
\hline BAWW & $\begin{array}{l}\text { Warbler } \\
\text { Brown-headed }\end{array}$ & Mniotilta varia \\
\hline $\mathrm{BHCO}$ & Cowbird & Molothrus ater \\
\hline BWTE & Blue-winged Teal & Anas discors \\
\hline KILL & Killdeer & Charadrius vociferus \\
\hline LEFL & Least Flycatcher & Empidonax minimus \\
\hline MALL & Mallard & Anas platyrhynchos \\
\hline MAWA & Magnolia Warbler & $\begin{array}{l}\text { Setophaga magnolia } \\
\text { Oporornis }\end{array}$ \\
\hline MOWA & Mourning Warbler & philadelphia \\
\hline NOPI & Northern Pintail & Anas acuta \\
\hline NSHO & Northern Shoveler & Anas clypeata \\
\hline RUDU & Ruddy Duck & Oxyura jamaicensis \\
\hline RWBL & Red-winged Blackbird & $\begin{array}{l}\text { Agelaius phoeniceus } \\
\text { Passerculus }\end{array}$ \\
\hline SAVS & Savannah Sparrow & sandwichensis \\
\hline SORA & Sora & Porzana carolina \\
\hline SOSP & Song Sparrow & Melospiza melodia \\
\hline VESP & $\begin{array}{l}\text { Vesper Sparrow } \\
\text { Yellow-headed }\end{array}$ & $\begin{array}{l}\text { Pooecetes gramineus } \\
\text { Xanthocephalus }\end{array}$ \\
\hline YHBL & Blackbird & xanthocephalus \\
\hline YEWA & Yellow Warbler & Setophaga petechia \\
\hline
\end{tabular}

\begin{tabular}{|c|c|c|c|c|c|c|c|c|c|c|}
\hline 0.66 & 0.16 & 0.56 & 0.72 & 2.08 & 60.26 & 0.04 & 0.82 & 0.67 & 0.34 & 25 \\
\hline 0.70 & 0.14 & 0.53 & 0.72 & 2.95 & 62.51 & 0.01 & 0.70 & 0.62 & 0.42 & 8 \\
\hline 0.29 & 0.25 & 0.29 & 0.53 & 4.93 & 79.90 & 0.00 & 1.00 & 0.99 & 0.95 & 16 \\
\hline 0.25 & 0.14 & 0.25 & 0.54 & 2.44 & 62.51 & 0.03 & 0.86 & 0.67 & 0.41 & 20 \\
\hline 0.66 & 0.16 & 0.55 & 0.72 & 2.08 & 52.59 & 0.05 & 0.78 & 0.50 & 0.20 & 9 \\
\hline 0.66 & 0.25 & 0.54 & 0.72 & 3.62 & 72.14 & 0.00 & 1.00 & 0.96 & 0.69 & 13 \\
\hline 0.54 & 0.16 & 0.36 & 0.60 & 2.50 & 63.41 & 0.02 & 0.94 & 0.79 & 0.50 & 20 \\
\hline 0.70 & 0.16 & 0.66 & 0.72 & 3.72 & 77.91 & 0.00 & 0.84 & 0.76 & 0.42 & 13 \\
\hline 0.29 & 0.14 & 0.28 & 0.60 & 1.85 & 58.92 & 0.04 & 0.89 & 0.70 & 0.34 & 19 \\
\hline 0.14 & 0.14 & 0.14 & 0.60 & 3.62 & 76.20 & 0.01 & 0.96 & 0.87 & 0.63 & 22 \\
\hline 0.26 & 0.16 & 0.27 & 0.66 & 3.68 & 69.53 & 0.01 & 0.97 & 0.88 & 0.62 & 14 \\
\hline 0.70 & 0.14 & 0.66 & 0.72 & 3.70 & 66.00 & 0.02 & 0.80 & 0.67 & 0.42 & 6 \\
\hline 0.70 & 0.28 & 0.66 & 0.72 & 4.67 & 69.60 & 0.01 & 0.94 & 0.75 & 0.44 & 5 \\
\hline 0.54 & 0.28 & 0.53 & 0.66 & 6.95 & 87.45 & 0.00 & 1.00 & 0.99 & 0.98 & 11 \\
\hline 0.51 & 0.27 & 0.46 & 0.56 & 5.09 & 75.48 & 0.00 & 0.99 & 0.98 & 0.87 & 12 \\
\hline 0.25 & 0.14 & 0.25 & 0.29 & 4.85 & 72.23 & 0.00 & 1.00 & 1.00 & 0.96 & 22 \\
\hline 0.51 & 0.28 & 0.51 & 0.56 & 7.54 & 86.66 & 0.00 & 1.00 & 1.00 & 0.98 & 10 \\
\hline 0.28 & 0.19 & 0.27 & 0.53 & 4.03 & 70.63 & 0.00 & 0.99 & 0.99 & 0.94 & 20 \\
\hline 0.29 & 0.16 & 0.27 & 0.57 & 4.79 & 70.00 & 0.00 & 1.00 & 0.99 & 0.91 & 17 \\
\hline 0.70 & 0.54 & 0.70 & 0.72 & 10.00 & 100.00 & 0.00 & 0.96 & 0.88 & 0.82 & 4 \\
\hline 0.56 & 0.29 & 0.56 & 0.72 & 4.38 & 53.23 & 0.00 & 0.99 & 0.89 & 0.70 & 5 \\
\hline 0.25 & 0.14 & 0.25 & 0.36 & 5.90 & 79.73 & 0.00 & 1.00 & 1.00 & 0.97 & 20 \\
\hline
\end{tabular}


Fig. A2.1. Scatter plots representing abundance of species that were significant negative $(\operatorname{sum}(z-))$ indicators of a gradient of increasing agricultural conversion in east-central Alberta (ECAB) at wetland (A) and landscape (B) scales.

A2.1A. Wetland scale
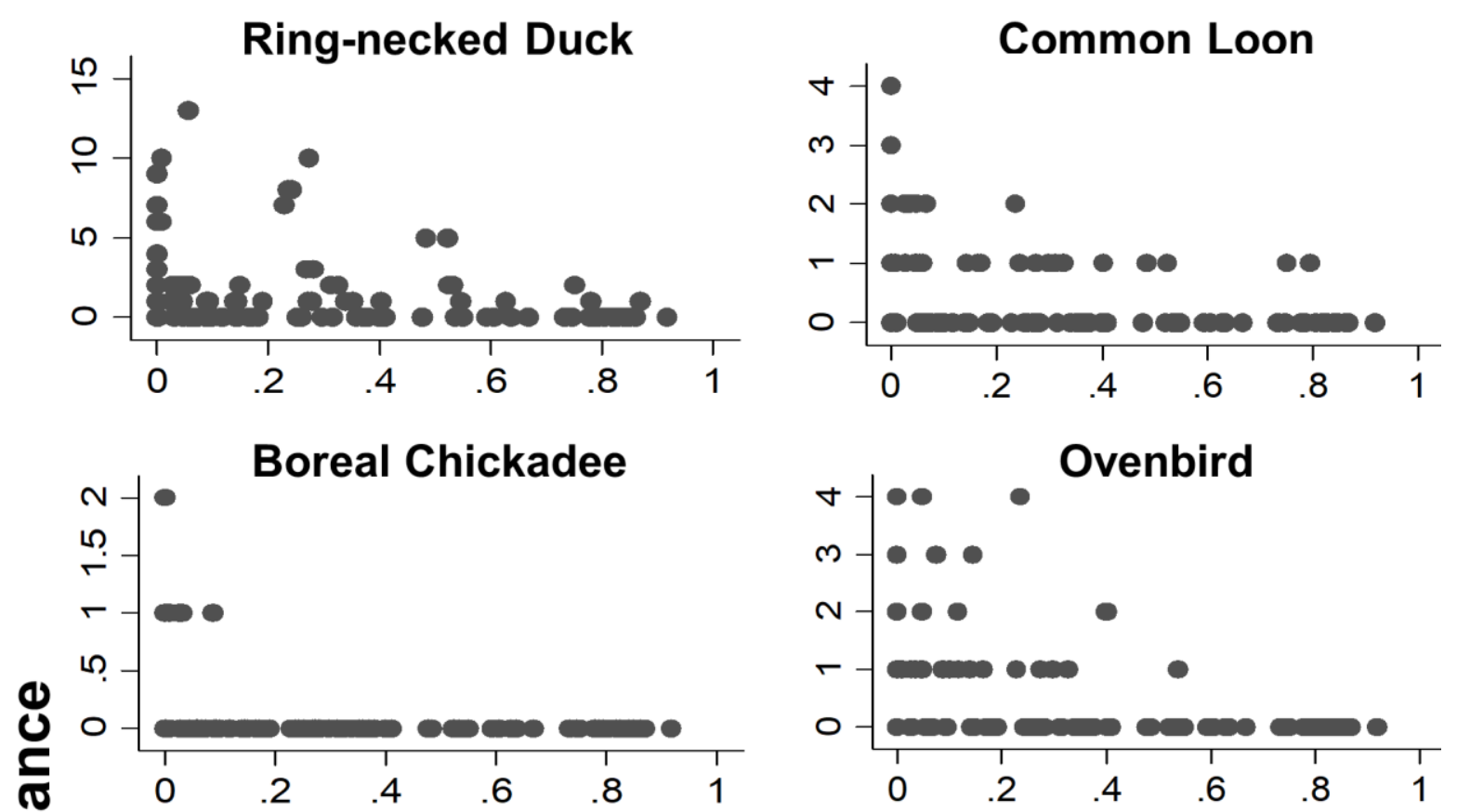

Swainson's Thrush

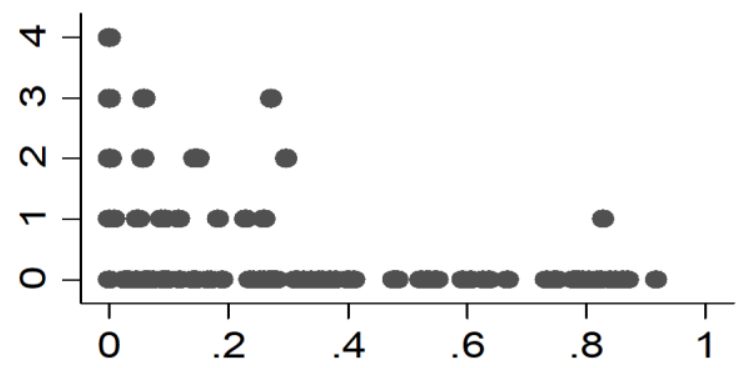

Dark-eyed Junco
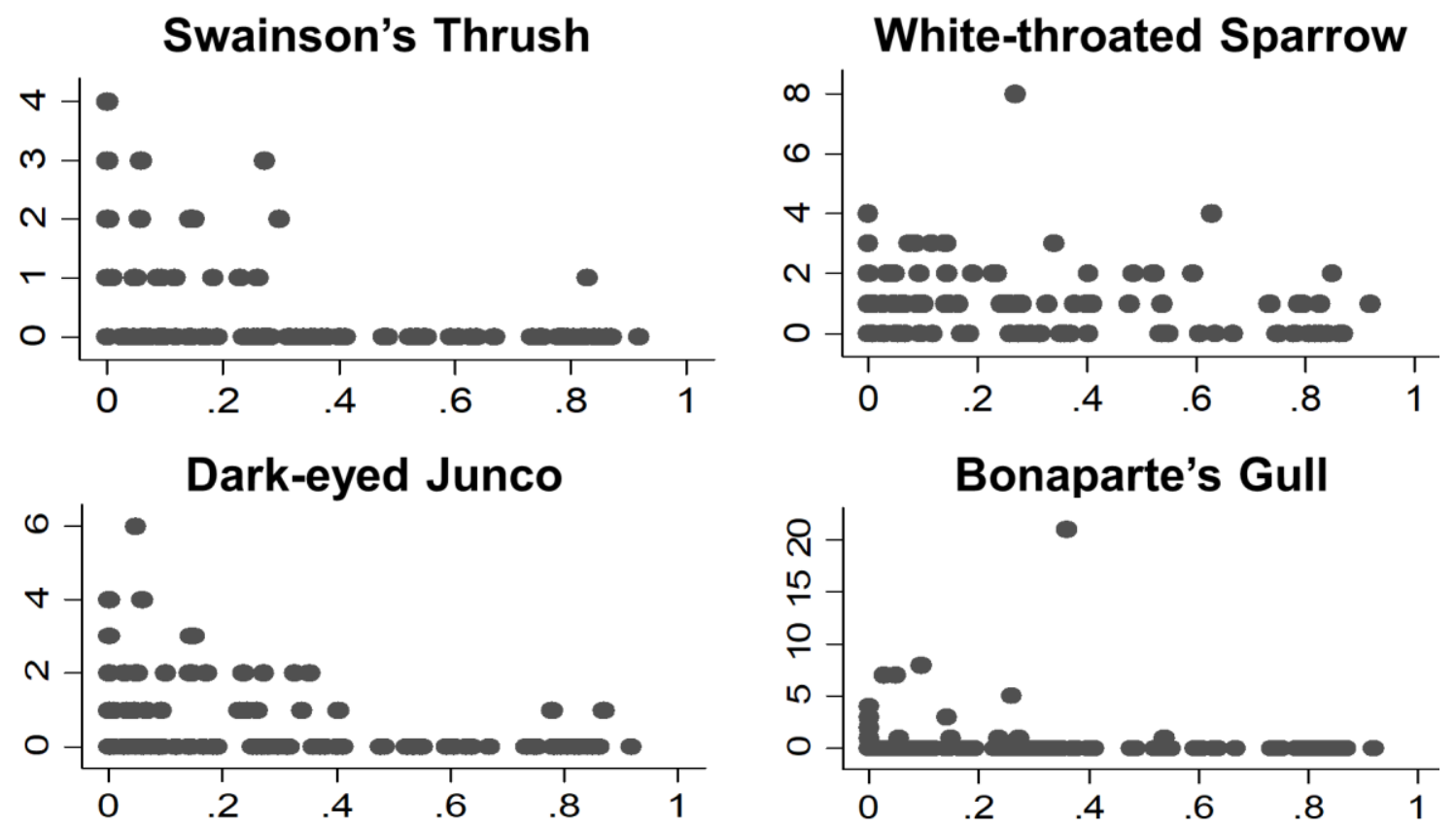

Bonaparte's Gull

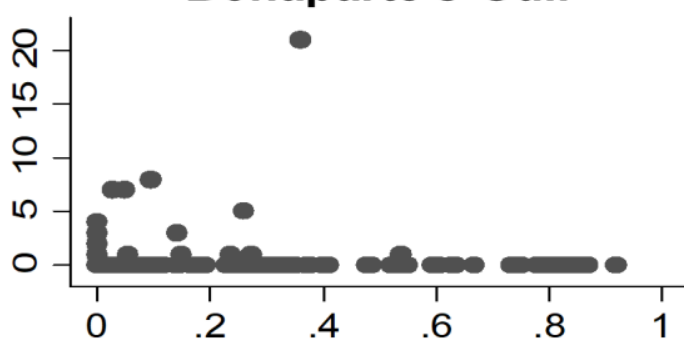

Proportion converted to agriculture 

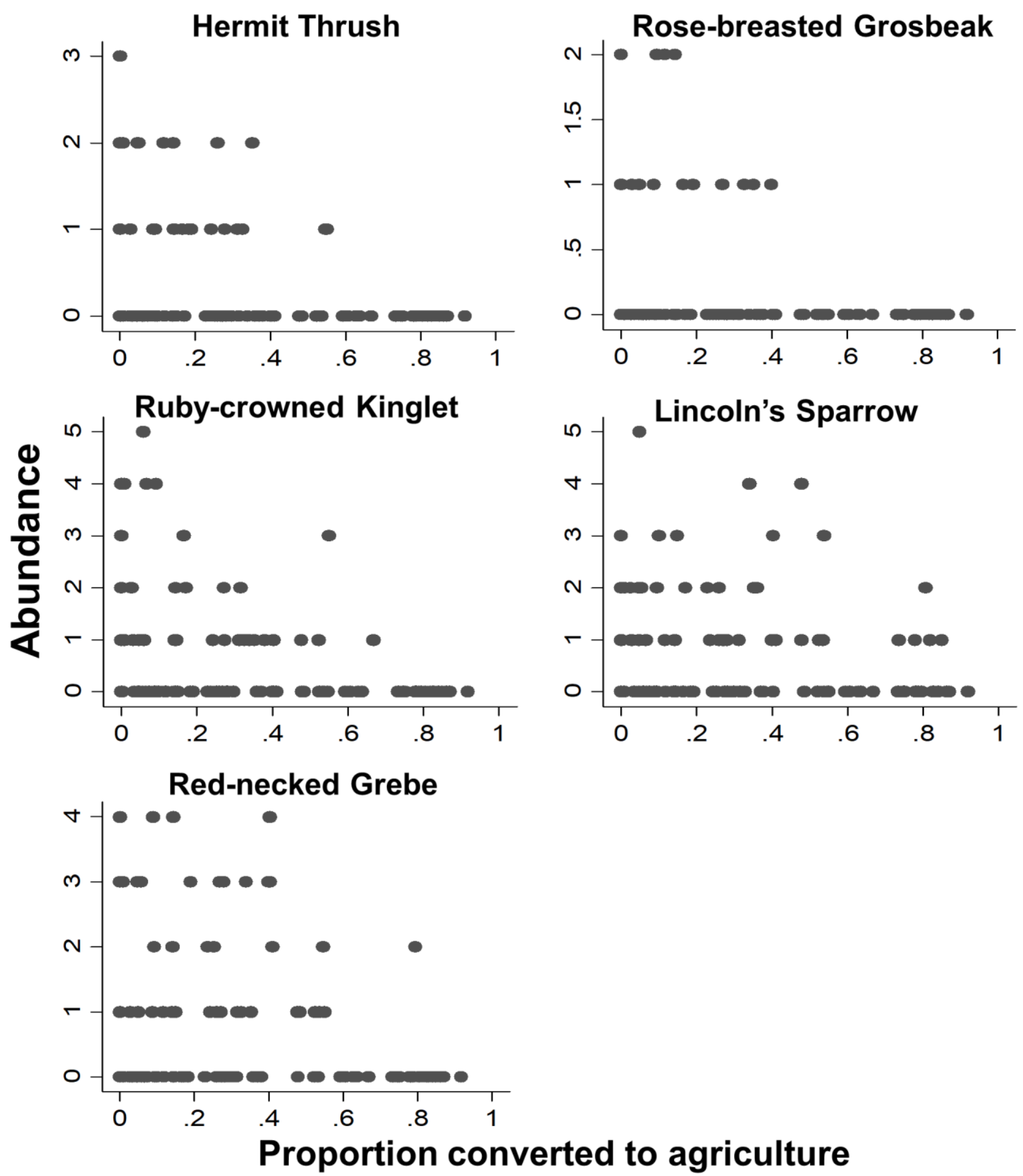
A2.1B. Landscape scale
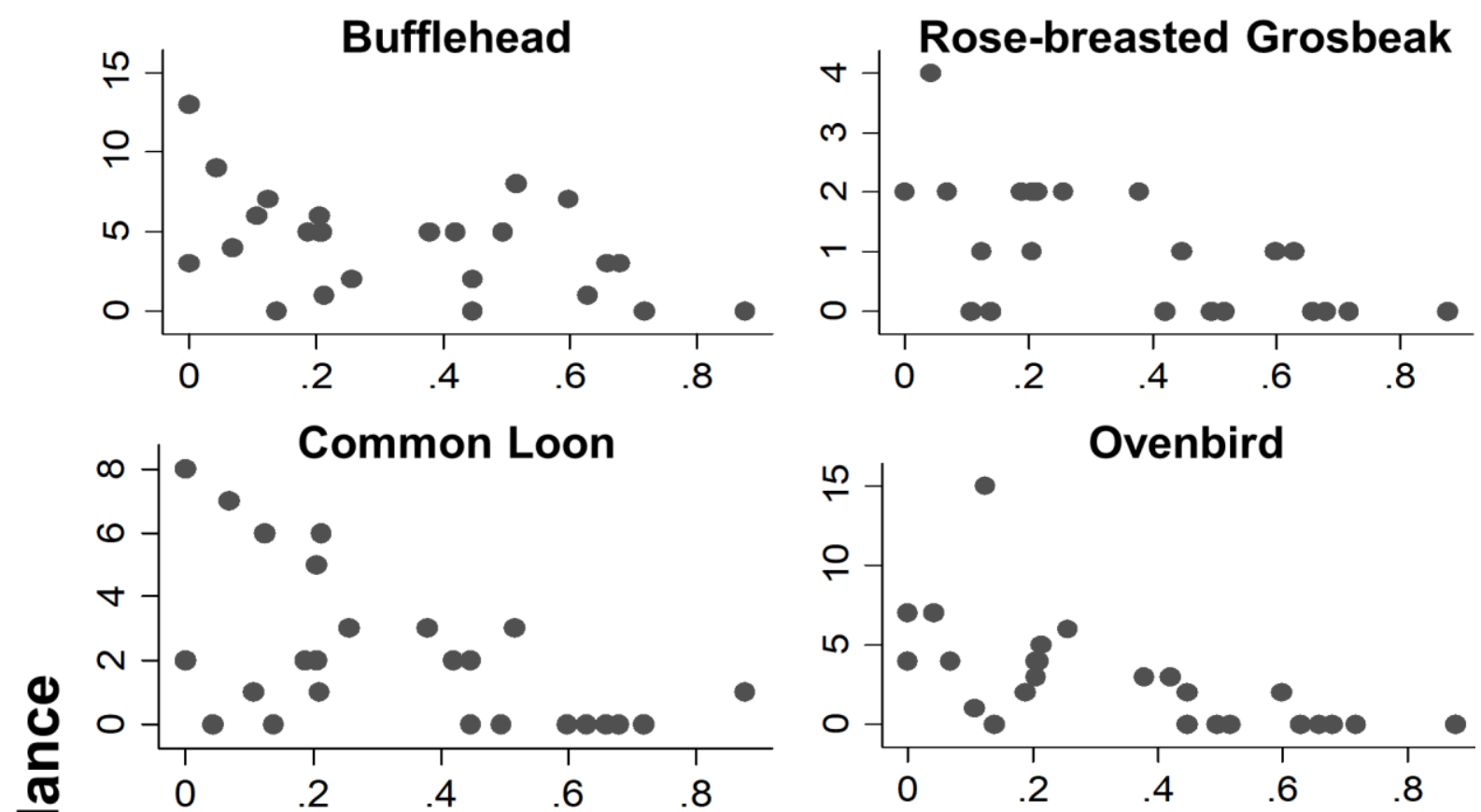

은
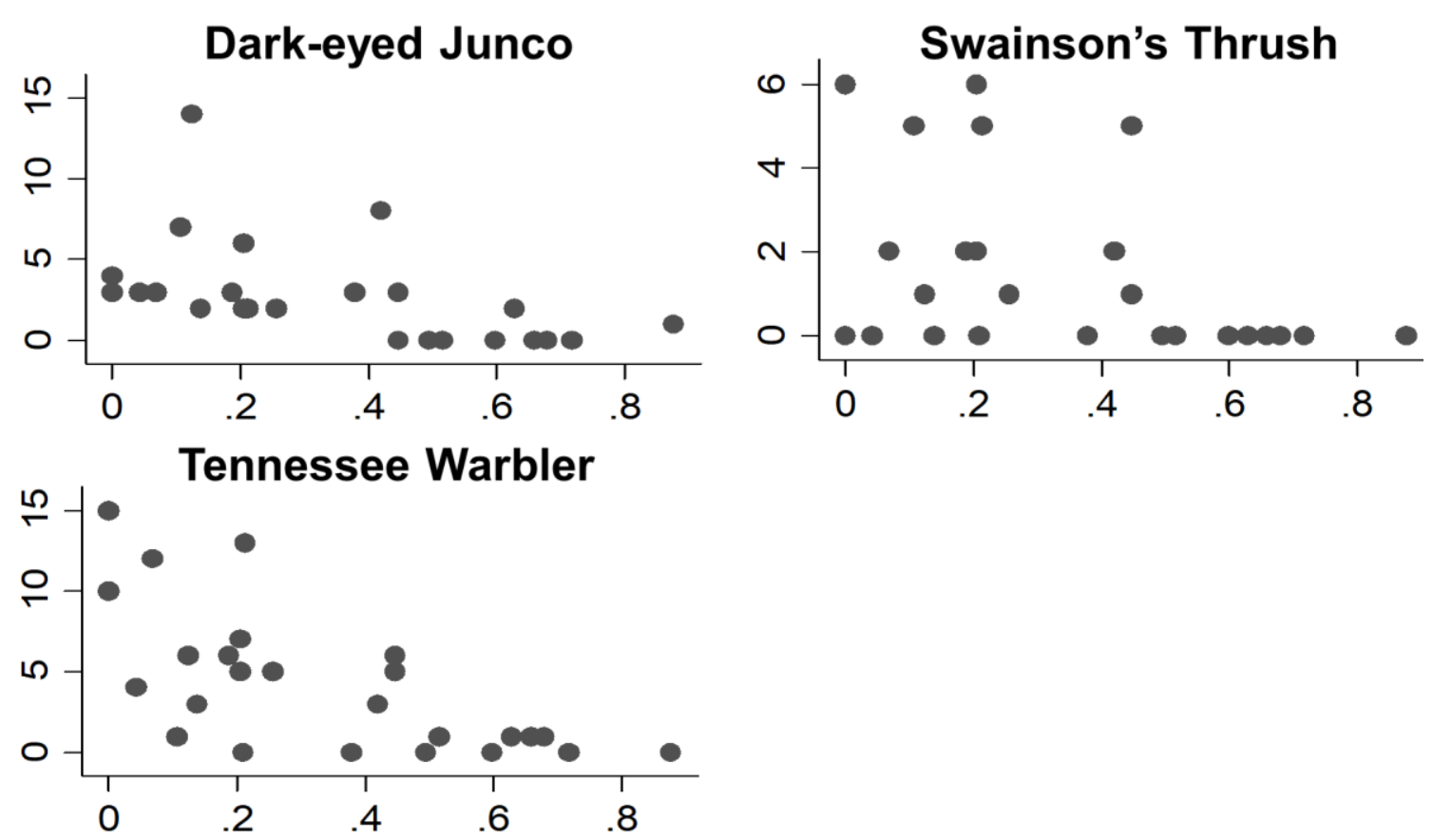

Proportion converted to agriculture 
Fig. A3.1. Scatter plots representing abundance of species that were significant positive $(\operatorname{sum}(\mathrm{z}+))$ indicators of a gradient of increasing agricultural conversion in east central Alberta (ECAB) at wetland (A) and landscape (B) scales.

A3.1A. Wetland scale

American Coot
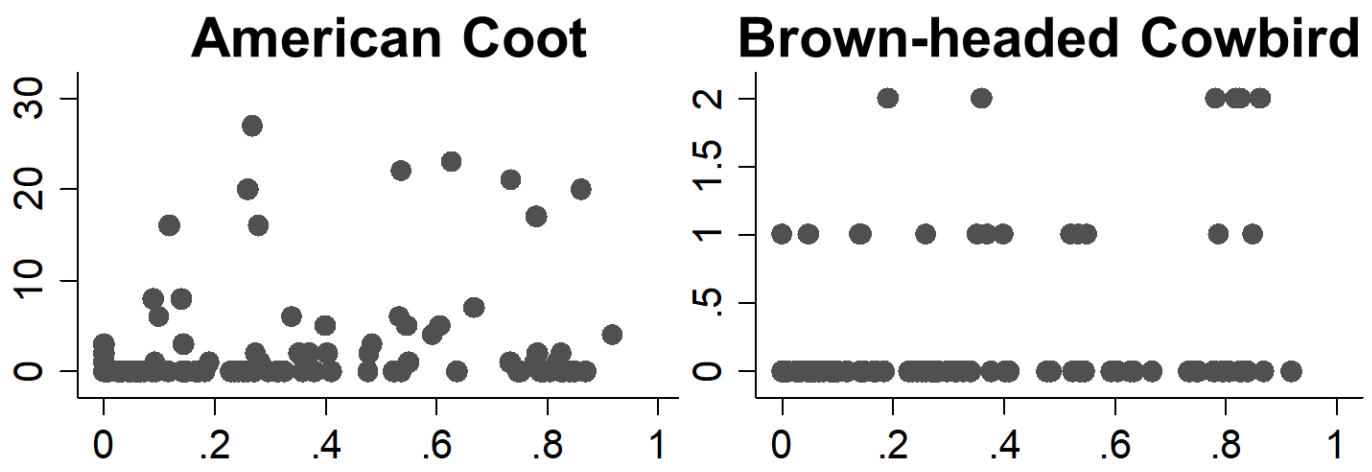

Yellow Warbler
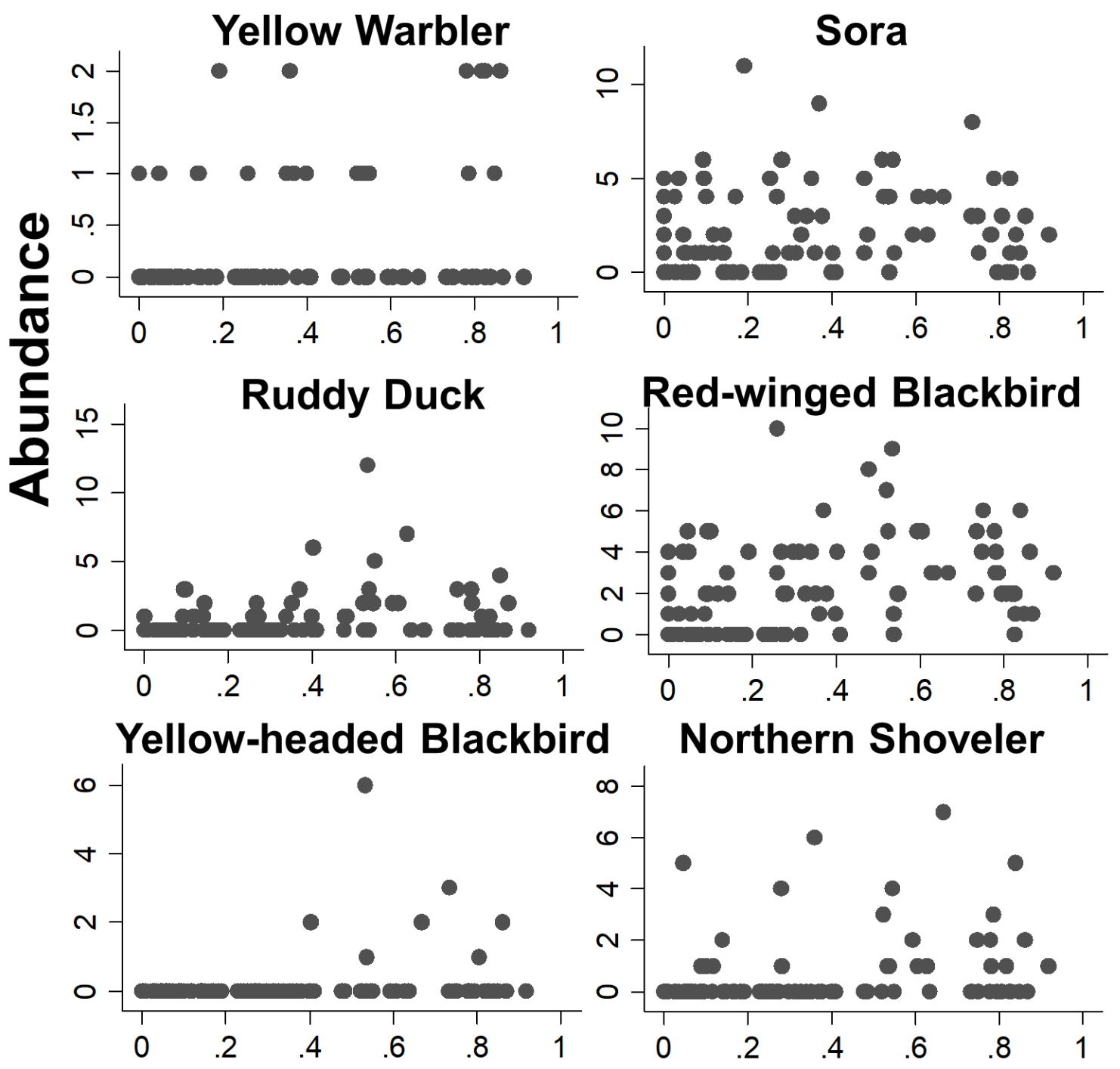

Proportion converted to agriculture 


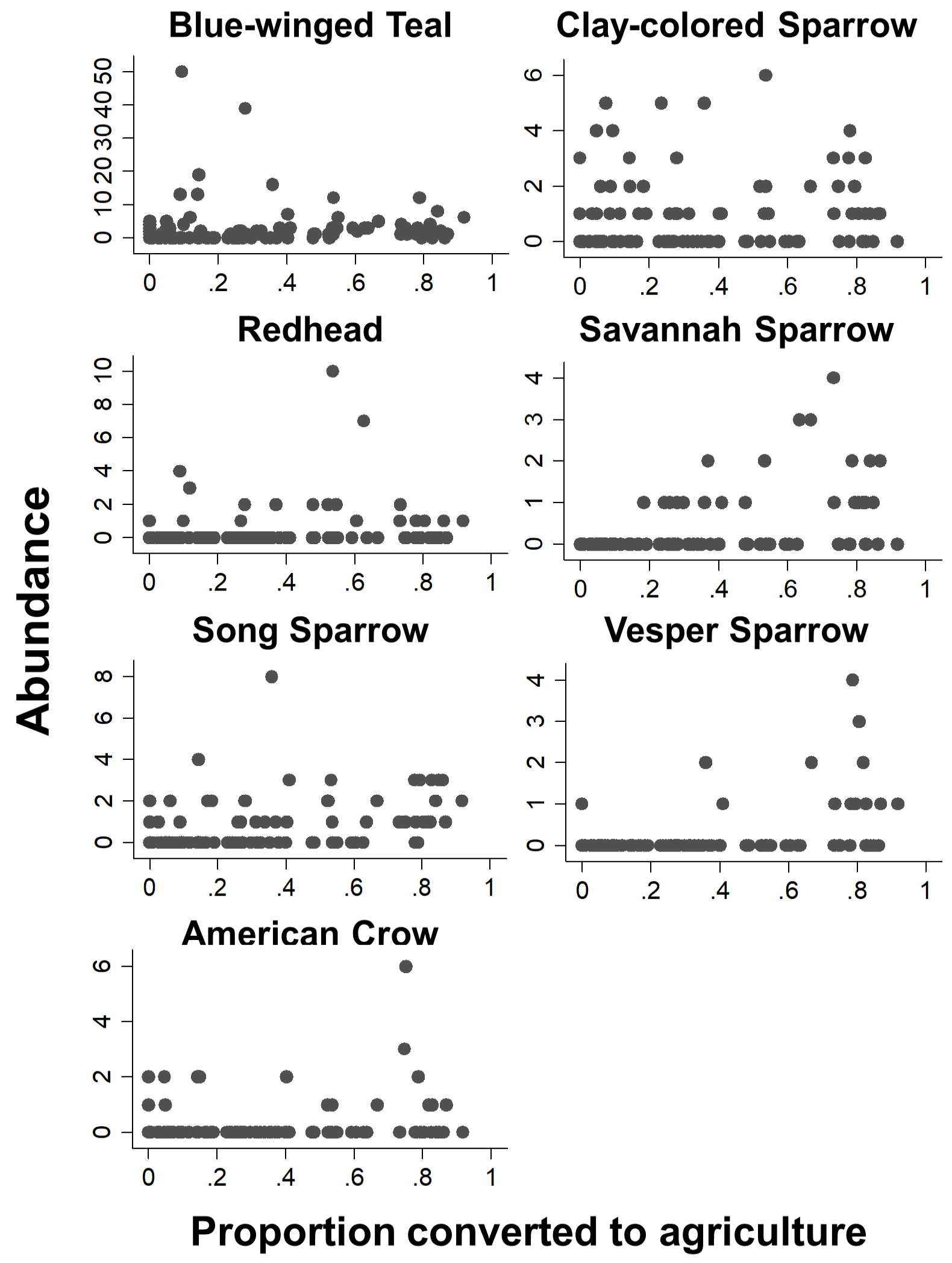


A3.1B. Landscape scale
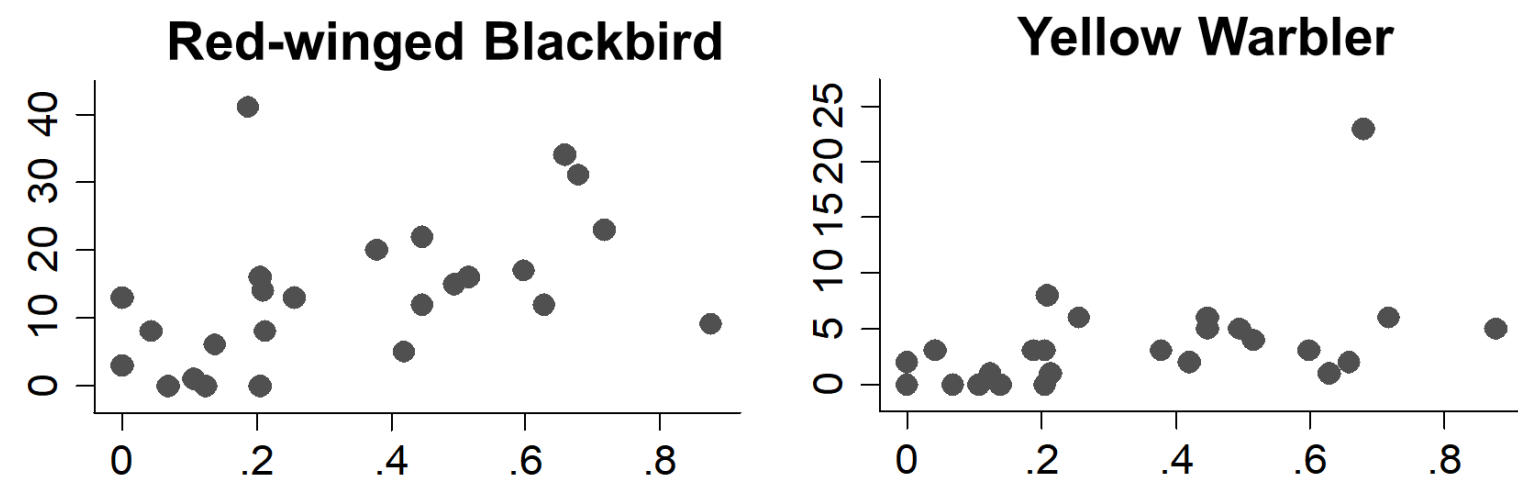

Blackburnian Warbler

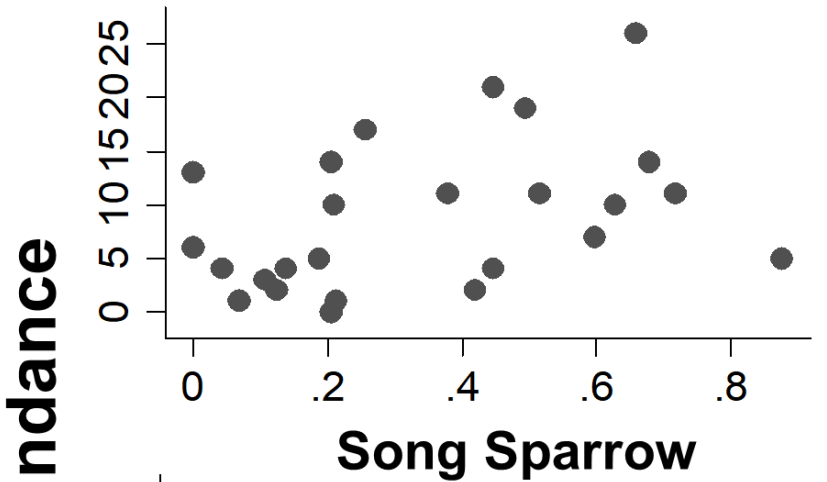

American Coot

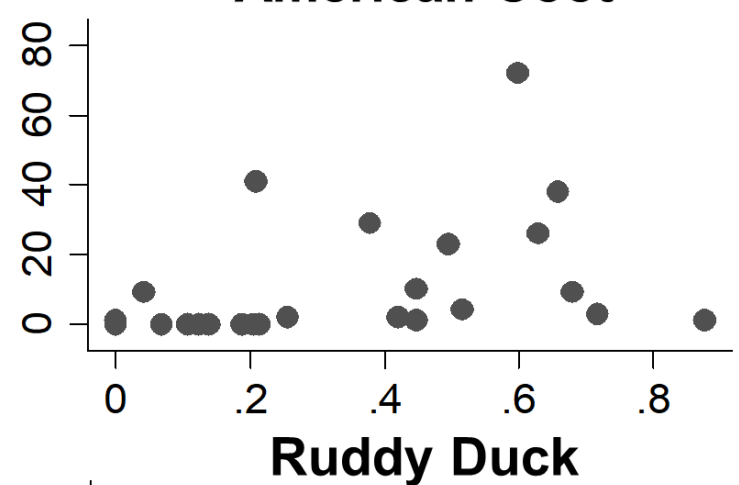

委
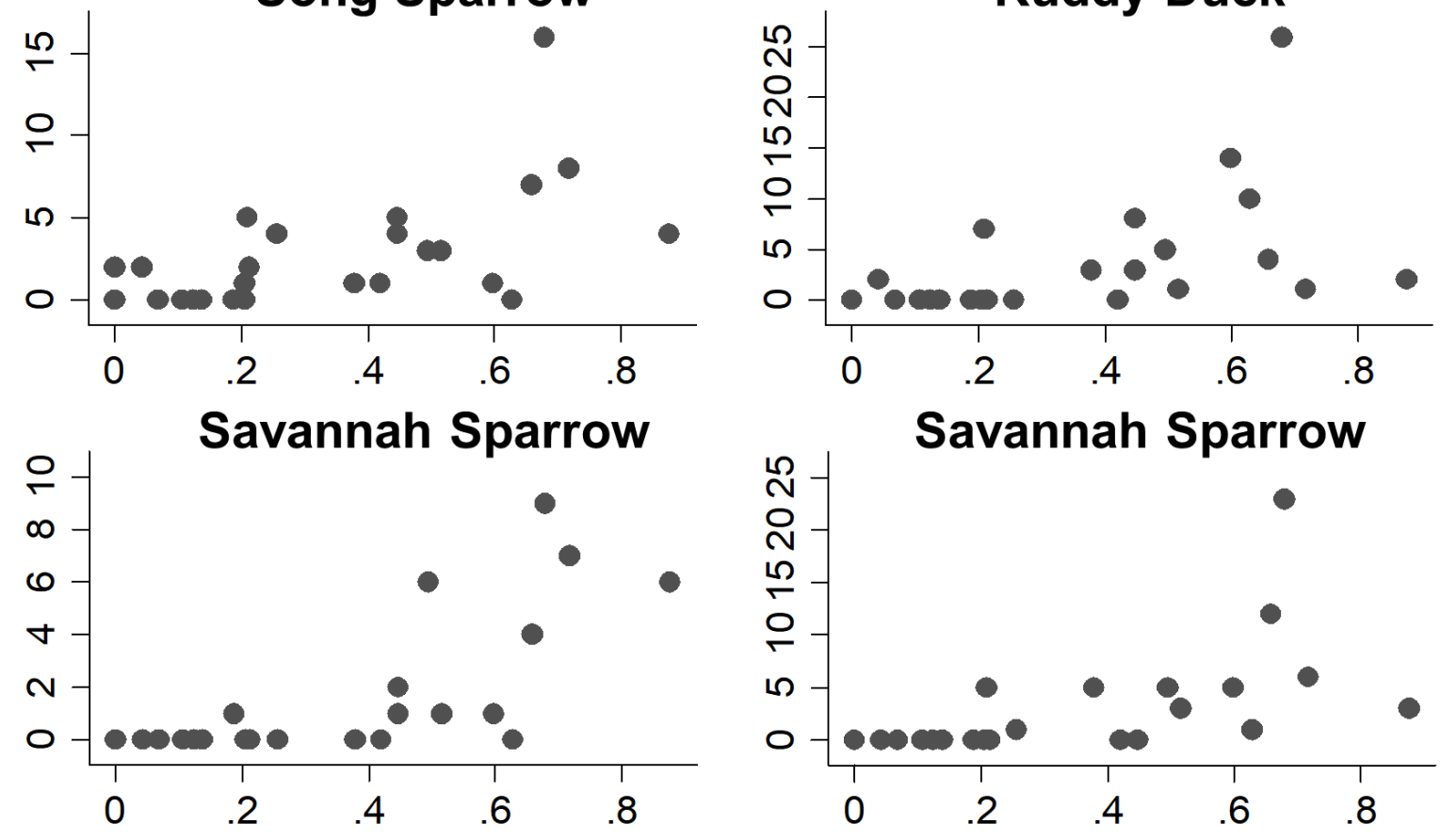

Proportion converted to agriculture 
Table A4.1. Individual species results from TITAN from bird surveys conducted in the Duck Mountain, Manitoba (DMMB) study area. Species codes, common names, scientific names, indicator scores (IndVal), change-points (Cp) and percentiles (5\%, 50\%, 95\%), for declining (-) and increasing taxa (+) in response to agricultural conversion at the wetland (A) and landscape (B) scales. Note that all significant indicator species are shown but that only species that met significance criteria for $P(\leq 0.05)$, purity $(\geq 0.95)$, and reliability ( $\geq 0.95$, and $\geq 0.9$ for at 0.05 , and 0.01 , respectively) are included in the figures. $P$ is the probability of getting an equal or larger IndVal using 250 random permutations. IndVal is the unstandardized indicator score, $\mathrm{z}$ is the standardized indicator value and $\mathrm{N}$ is the frequency of species occurrence among landscapes/wetlands sampled.

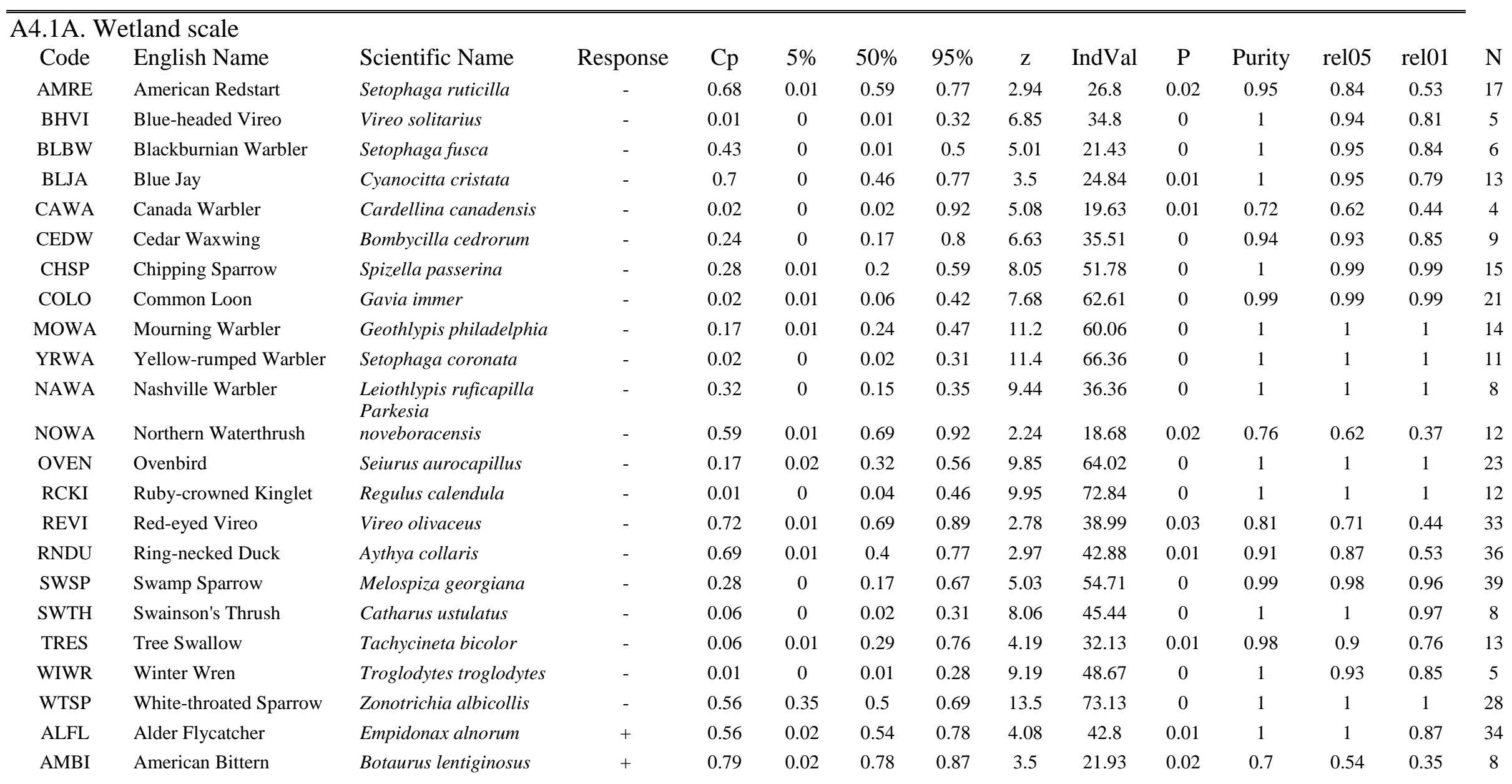




\begin{tabular}{|c|c|c|c|c|c|c|c|c|c|c|c|c|c|c|}
\hline AMCO & American Coot & Fulica americana & + & 0.68 & 0.4 & 0.64 & 0.78 & 8.03 & 50.55 & 0 & 1 & 1 & 1 & 22 \\
\hline AMCR & American Crow & Corvus brachyrhynchos & + & 0.89 & 0.72 & 0.88 & 0.92 & 6.81 & 89.23 & 0 & 1 & 0.98 & 0.9 & 15 \\
\hline BAOR & Baltimore Oriole & Icterus galbula & + & 0.81 & 0.67 & 0.79 & 0.87 & 5.54 & 21.87 & 0.01 & 0.94 & 0.76 & 0.58 & 4 \\
\hline BARS & Barn Swallow & Hirundo rustica & + & 0.92 & 0.5 & 0.88 & 0.92 & 5.64 & 63.35 & 0.01 & 0.99 & 0.92 & 0.66 & 6 \\
\hline $\mathrm{BHCO}$ & Brown-headed Cowbird & Molothrus ater & + & 0.17 & 0.06 & 0.35 & 0.77 & 2.33 & 29.09 & 0.04 & 0.87 & 0.81 & 0.34 & 16 \\
\hline BUFF & Bufflehead & Bucephala albeola & + & 0.87 & 0.46 & 0.83 & 0.89 & 3.9 & 54.46 & 0.01 & 0.93 & 0.91 & 0.67 & 25 \\
\hline BWTE & Blue-winged Teal & Anas discors & + & 0.38 & 0.31 & 0.67 & 0.85 & 4.93 & 40.71 & 0 & 1 & 1 & 0.96 & 24 \\
\hline CANV & Canvasback & Aythya valisineria & + & 0.68 & 0.49 & 0.73 & 0.87 & 2.54 & 11.76 & 0.05 & 0.98 & 0.71 & 0.38 & 4 \\
\hline CCSP & Clay-colored Sparrow & Spizella pallida & + & 0.43 & 0.33 & 0.54 & 0.78 & 10.2 & 65.73 & 0 & 1 & 1 & 1 & 31 \\
\hline COSN & Wilson's Snipe & Gallinago delicata & + & 0.83 & 0 & 0.82 & 0.89 & 2.65 & 39.48 & 0.04 & 0.86 & 0.76 & 0.42 & 23 \\
\hline EAKI & Eastern Kingbird & Tyrannus tyrannus & + & 0.92 & 0 & 0.74 & 0.92 & 1.71 & 28.4 & 0.02 & 0.6 & 0.31 & 0.13 & 5 \\
\hline GADW & Gadwall & Anas strepera & + & 0.88 & 0.43 & 0.85 & 0.89 & 4.02 & 30.56 & 0.03 & 0.93 & 0.71 & 0.32 & 5 \\
\hline GRCA & Gray Catbird & Dumetella carolinensis & + & 0.54 & 0.42 & 0.68 & 0.76 & 5.06 & 25.64 & 0 & 1 & 0.99 & 0.86 & 10 \\
\hline HOWR & House Wren & Troglodytes aedon & + & 0.17 & 0.06 & 0.4 & 0.77 & 3.39 & 32.73 & 0.01 & 1 & 0.97 & 0.63 & 18 \\
\hline KILL & Killdeer & Charadrius vociferus & + & 0.5 & 0.29 & 0.62 & 0.83 & 2.38 & 17.56 & 0.04 & 0.97 & 0.71 & 0.37 & 9 \\
\hline LEFL & Least Flycatcher & Empidonax minimus & + & 0.33 & 0.06 & 0.38 & 0.88 & 2.51 & 23.82 & 0.03 & 0.96 & 0.89 & 0.46 & 14 \\
\hline LESC & Lesser Scaup & Aythya affinis & + & 0.32 & 0.28 & 0.43 & 0.89 & 3.38 & 28 & 0.01 & 0.99 & 0.96 & 0.65 & 14 \\
\hline MAWR & Marsh Wren & Cistothorus palustris & + & 0.88 & 0.78 & 0.83 & 0.88 & 6.78 & 40.93 & 0.01 & 0.98 & 0.91 & 0.79 & 5 \\
\hline NOFL & Northern Flicker & Colaptes auratus & + & 0.74 & 0.43 & 0.75 & 0.83 & 2.84 & 16.31 & 0.02 & 0.99 & 0.67 & 0.49 & 6 \\
\hline PBGR & Pied-billed Grebe & Podilymbus podiceps & + & 0.44 & 0.28 & 0.54 & 0.79 & 3.16 & 33.05 & 0.01 & 0.98 & 0.96 & 0.73 & 21 \\
\hline PHVI & Philadelphia Vireo & Vireo philadelphicus & + & 0.78 & 0.29 & 0.77 & 0.87 & 2.92 & 21.11 & 0.04 & 0.93 & 0.73 & 0.39 & 8 \\
\hline REDH & Redhead & Aythya americana & + & 0.74 & 0.69 & 0.76 & 0.88 & 5.44 & 23.08 & 0 & 1 & 0.96 & 0.79 & 6 \\
\hline RNGR & Red-necked Grebe & Podiceps grisegena & + & 0.06 & 0.01 & 0.28 & 0.77 & 4.89 & 56.55 & 0 & 1 & 1 & 0.97 & 37 \\
\hline RUDU & Ruddy Duck & Oxyura jamaicensis & + & 0.44 & 0.32 & 0.46 & 0.76 & 5.62 & 41.86 & 0 & 1 & 1 & 1 & 18 \\
\hline RWBL & Red-winged Blackbird & $\begin{array}{l}\text { Agelaius phoeniceus } \\
\text { Passerculus }\end{array}$ & + & 0.42 & 0.28 & 0.42 & 0.6 & 7.68 & 68.94 & 0 & 0.99 & 0.99 & 0.99 & 52 \\
\hline SAVS & Savannah Sparrow & sandwichensis & + & 0.43 & 0.32 & 0.48 & 0.87 & 5.06 & 33.89 & 0 & 1 & 0.99 & 0.9 & 17 \\
\hline SORA & Sora & Porzana carolina & + & 0.17 & 0.02 & 0.31 & 0.83 & 4.09 & 54.27 & 0.01 & 1 & 0.99 & 0.91 & 38 \\
\hline SOSP & Song Sparrow & Melospiza melodia & + & 0.24 & 0.02 & 0.28 & 0.7 & 8.49 & 76.66 & 0 & 1 & 1 & 1 & 53 \\
\hline VESP & Vesper Sparrow & Pooecetes gramineus & + & 0.67 & 0.46 & 0.7 & 0.77 & 4.92 & 20 & 0 & 1 & 0.93 & 0.69 & 7 \\
\hline WEME & Western Meadowlark & $\begin{array}{l}\text { Sturnella neglecta } \\
\text { Xanthocephalus }\end{array}$ & + & 0.44 & 0.4 & 0.73 & 0.92 & 2.42 & 13.95 & 0.02 & 0.96 & 0.63 & 0.38 & 6 \\
\hline YHBL & Yellow-headed Blackbird & xanthocephalus & + & 0.78 & 0.75 & 0.77 & 0.83 & 7.63 & 33.33 & 0 & 0.99 & 0.97 & 0.91 & 6 \\
\hline YEWA & Yellow Warbler & Setophaga petechia & + & 0.69 & 0.06 & 0.64 & 0.77 & 4.4 & 45.23 & 0 & 0.99 & 0.99 & 0.89 & 32 \\
\hline
\end{tabular}




\begin{tabular}{|c|c|c|c|c|c|c|c|c|c|c|c|c|c|c|}
\hline \multicolumn{15}{|c|}{ A4.1B. Landscape scale } \\
\hline Code & Common Name & Scientific Name & Response & $\mathrm{Cp}$ & $5 \%$ & $50 \%$ & $95 \%$ & $\mathrm{z}$ & IndVal & $\mathrm{P}$ & Purity & rel05 & rel01 & $\mathrm{N}$ \\
\hline ALFL & Alder Flycatcher & Empidonax alnorum & - & 0.78 & 0.13 & 0.60 & 0.83 & 2.25 & 35.89 & 0.04 & 0.91 & 0.84 & 0.50 & 41 \\
\hline $\mathrm{BOCH}$ & Boreal Chickadee & Poecile hudsonicus & - & 0.13 & 0.03 & 0.12 & 0.15 & 7.22 & 22.73 & 0.00 & 1.00 & 0.97 & 0.82 & 5 \\
\hline BOGU & Bonaparte's Gull & Larus philadelphia & - & 0.41 & 0.03 & 0.34 & 0.52 & 3.72 & 19.53 & 0.01 & 1.00 & 0.95 & 0.72 & 13 \\
\hline CHSP & Chipping Sparrow & Spizella passerina & - & 0.65 & 0.08 & 0.19 & 0.73 & 2.85 & 28.37 & 0.02 & 0.97 & 0.89 & 0.54 & 26 \\
\hline COLO & Common Loon & Gavia immer & - & 0.11 & 0.06 & 0.12 & 0.30 & 8.48 & 57.83 & 0.00 & 1.00 & 1.00 & 1.00 & 29 \\
\hline CONW & Connecticut Warbler & Oporornis agilis & - & 0.35 & 0.15 & 0.34 & 0.42 & 4.18 & 22.20 & 0.00 & 0.93 & 0.91 & 0.78 & 16 \\
\hline GRAJ & Gray Jay & Perisoreus canadensis & - & 0.06 & 0.03 & 0.07 & 0.29 & 6.93 & 27.03 & 0.01 & 1.00 & 0.94 & 0.77 & 6 \\
\hline HETH & Hermit Thrush & $\begin{array}{l}\text { Catharus guttatus } \\
\text { Ammodramus }\end{array}$ & - & 0.42 & 0.11 & 0.37 & 0.51 & 6.66 & 37.58 & 0.00 & 1.00 & 1.00 & 0.98 & 27 \\
\hline LCSP & LeConte's Sparrow & leconteii & - & 0.21 & 0.12 & 0.27 & 0.91 & 3.64 & 31.04 & 0.01 & 0.81 & 0.76 & 0.61 & 29 \\
\hline LISP & $\begin{array}{l}\text { Lincoln's Sparrow } \\
\text { Yellow-rumped }\end{array}$ & Melospiza lincolnii & - & 0.58 & 0.10 & 0.53 & 0.83 & 3.11 & 41.05 & 0.02 & 1.00 & 0.95 & 0.72 & 45 \\
\hline YRWA & Warbler & Setophaga coronata & - & 0.19 & 0.05 & 0.24 & 0.87 & 2.92 & 38.46 & 0.02 & 0.88 & 0.84 & 0.63 & 47 \\
\hline NOFL & Northern Flicker & Colaptes auratus & - & 0.34 & 0.09 & 0.31 & 0.87 & 1.97 & 8.96 & 0.02 & 0.77 & 0.49 & 0.26 & 6 \\
\hline OVEN & $\begin{array}{l}\text { Ovenbird } \\
\text { Rose-breasted }\end{array}$ & $\begin{array}{l}\text { Seiurus aurocapillus } \\
\text { Pheucticus }\end{array}$ & - & 0.21 & 0.13 & 0.27 & 0.56 & 7.14 & 42.53 & 0.00 & 1.00 & 1.00 & 0.99 & 28 \\
\hline RBGR & Grosbeak & ludovicianus & - & 0.45 & 0.13 & 0.42 & 0.54 & 4.51 & 20.63 & 0.00 & 1.00 & 0.97 & 0.86 & 13 \\
\hline RCKI & Ruby-crowned Kinglet & Regulus calendula & - & 0.47 & 0.15 & 0.54 & 0.76 & 4.21 & 30.51 & 0.00 & 1.00 & 1.00 & 0.83 & 29 \\
\hline RNDU & Ring-necked Duck & Aythya collaris & - & 0.10 & 0.07 & 0.35 & 0.64 & 3.92 & 50.11 & 0.00 & 1.00 & 0.99 & 0.87 & 42 \\
\hline RNGR & Red-necked Grebe & Podiceps grisegena & - & 0.64 & 0.36 & 0.62 & 0.73 & 5.17 & 45.77 & 0.00 & 0.97 & 0.97 & 0.91 & 40 \\
\hline SACR & Sandhill Crane & Grus canadensis & - & 0.11 & 0.04 & 0.11 & 0.30 & 4.70 & 20.50 & 0.00 & 1.00 & 0.88 & 0.67 & 6 \\
\hline DEJU & Dark-eyed Junco & Junco hyemalis & - & 0.34 & 0.17 & 0.31 & 0.47 & 7.28 & 40.20 & 0.00 & 1.00 & 1.00 & 1.00 & 31 \\
\hline SWSP & Swamp Sparrow & Melospiza georgiana & - & 0.10 & 0.06 & 0.24 & 0.64 & 2.82 & 35.42 & 0.03 & 0.95 & 0.90 & 0.66 & 29 \\
\hline SWTH & Swainson's Thrush & Catharus ustulatus & - & 0.30 & 0.13 & 0.31 & 0.47 & 5.87 & 27.44 & 0.00 & 0.97 & 0.97 & 0.95 & 17 \\
\hline TEWA & Tennessee Warbler & Oreothlypis peregrina & - & 0.35 & 0.12 & 0.36 & 0.68 & 4.73 & 34.57 & 0.00 & 0.95 & 0.94 & 0.83 & 31 \\
\hline PAWA & $\begin{array}{l}\text { Palm Warbler } \\
\text { White-throated }\end{array}$ & Setophaga palmarum & - & 0.03 & 0.03 & 0.20 & 0.38 & 4.11 & 33.22 & 0.03 & 0.99 & 0.92 & 0.79 & 11 \\
\hline WTSP & $\begin{array}{l}\text { Sparrow } \\
\text { Yellow-bellied }\end{array}$ & Zonotrichia albicollis & - & 0.34 & 0.03 & 0.34 & 0.69 & 5.38 & 52.71 & 0.00 & 0.99 & 0.99 & 0.89 & 63 \\
\hline YBSA & Sapsucker & Sphyrapicus varius & - & 0.05 & 0.03 & 0.06 & 0.87 & 4.32 & 27.88 & 0.02 & 0.86 & 0.63 & 0.40 & 9 \\
\hline AGWT & Green-winged Teal & Anas crecca & + & 0.69 & 0.03 & 0.54 & 0.81 & 2.03 & 16.37 & 0.03 & 0.69 & 0.55 & 0.32 & 10 \\
\hline AMCO & American Coot & $\begin{array}{l}\text { Fulica americana } \\
\text { Corvus }\end{array}$ & + & 0.15 & 0.12 & 0.30 & 0.56 & 4.90 & 43.49 & 0.01 & 1.00 & 1.00 & 0.96 & 39 \\
\hline AMCR & American Crow & brachyrhynchos & + & 0.89 & 0.27 & 0.73 & 0.91 & 5.58 & 65.21 & 0.01 & 0.98 & 0.96 & 0.79 & 15 \\
\hline
\end{tabular}




\begin{tabular}{|c|c|c|c|c|c|c|c|c|c|c|c|c|c|c|}
\hline BAOR & Baltimore Oriole & Icterus galbula & + & 0.47 & 0.22 & 0.50 & 0.73 & 4.38 & 16.97 & 0.01 & 1.00 & 0.94 & 0.67 & 9 \\
\hline BBMA & $\begin{array}{l}\text { Black-billed Magpie } \\
\text { Brown-headed }\end{array}$ & Pica pica & + & 0.67 & 0.41 & 0.64 & 0.87 & 4.45 & 21.32 & 0.00 & 0.95 & 0.89 & 0.75 & 8 \\
\hline BHCO & Cowbird & Molothrus ater & + & 0.14 & 0.14 & 0.34 & 0.83 & 3.78 & 25.00 & 0.00 & 1.00 & 1.00 & 0.79 & 19 \\
\hline BWTE & Blue-winged Teal & Anas discors & + & 0.55 & 0.22 & 0.48 & 0.62 & 6.34 & 56.66 & 0.00 & 1.00 & 0.98 & 0.95 & 61 \\
\hline CCSP & Clay-colored Sparrow & Spizella pallida & + & 0.55 & 0.12 & 0.56 & 0.79 & 3.80 & 42.57 & 0.00 & 0.99 & 0.97 & 0.74 & 44 \\
\hline EAGR & Eared Grebe & Podiceps nigricollis & + & 0.60 & 0.52 & 0.62 & 0.83 & 4.62 & 12.00 & 0.02 & 0.96 & 0.74 & 0.52 & 3 \\
\hline GADW & Gadwall & Anas strepera & + & 0.76 & 0.03 & 0.67 & 0.84 & 3.47 & 15.15 & 0.03 & 0.67 & 0.52 & 0.35 & 5 \\
\hline HOWR & House Wren & Troglodytes aedon & + & 0.55 & 0.23 & 0.55 & 0.83 & 3.33 & 13.91 & 0.01 & 1.00 & 0.88 & 0.56 & 7 \\
\hline KILL & Killdeer & Charadrius vociferus & + & 0.56 & 0.15 & 0.54 & 0.81 & 4.36 & 26.27 & 0.00 & 0.94 & 0.91 & 0.72 & 18 \\
\hline LEFL & Least Flycatcher & Empidonax minimus & + & 0.30 & 0.06 & 0.29 & 0.88 & 2.32 & 27.81 & 0.05 & 0.79 & 0.68 & 0.39 & 32 \\
\hline MALL & Mallard & $\begin{array}{l}\text { Anas platyrhynchos } \\
\text { Oporornis }\end{array}$ & + & 0.14 & 0.04 & 0.15 & 0.86 & 2.15 & 39.91 & 0.04 & 0.98 & 0.86 & 0.46 & 52 \\
\hline MOWA & Mourning Warbler & philadelphia & + & 0.73 & 0.29 & 0.69 & 0.91 & 3.60 & 17.51 & 0.02 & 0.96 & 0.86 & 0.55 & 7 \\
\hline NOPI & Northern Pintail & Anas acuta & + & 0.55 & 0.17 & 0.54 & 0.78 & 2.76 & 11.24 & 0.01 & 0.87 & 0.51 & 0.25 & 6 \\
\hline NSHO & Northern Shoveler & Anas clypeata & + & 0.54 & 0.33 & 0.52 & 0.60 & 7.79 & 45.82 & 0.00 & 1.00 & 1.00 & 0.96 & 27 \\
\hline NSTS & Nelson's Sparrow & Ammodramus nelsoni & + & 0.30 & 0.21 & 0.31 & 0.57 & 2.24 & 8.77 & 0.05 & 0.91 & 0.43 & 0.18 & 5 \\
\hline PBGR & Pied-billed Grebe & Podilymbus podiceps & + & 0.51 & 0.09 & 0.47 & 0.91 & 3.25 & 25.87 & 0.01 & 0.91 & 0.84 & 0.58 & 23 \\
\hline RBNU & Red-breasted Nuthatch & Sitta canadensis & + & 0.35 & 0.14 & 0.38 & 0.56 & 1.61 & 8.59 & 0.04 & 0.80 & 0.48 & 0.23 & 6 \\
\hline REDH & Redhead & Aythya americana & + & 0.55 & 0.17 & 0.52 & 0.65 & 5.91 & 33.02 & 0.00 & 0.99 & 0.98 & 0.90 & 21 \\
\hline REVI & Red-eyed Vireo & Vireo olivaceus & + & 0.13 & 0.11 & 0.16 & 0.88 & 2.06 & 35.88 & 0.04 & 0.73 & 0.58 & 0.33 & 42 \\
\hline RUDU & Ruddy Duck & Oxyura jamaicensis & + & 0.36 & 0.13 & 0.37 & 0.52 & 6.50 & 38.98 & 0.00 & 1.00 & 1.00 & 1.00 & 32 \\
\hline RWBL & Red-winged Blackbird & $\begin{array}{l}\text { Agelaius phoeniceus } \\
\text { Passerculus }\end{array}$ & + & 0.38 & 0.23 & 0.36 & 0.43 & 10.54 & 67.10 & 0.00 & 1.00 & 1.00 & 1.00 & 66 \\
\hline SAVS & Savannah Sparrow & sandwichensis & + & 0.65 & 0.25 & 0.54 & 0.69 & 7.96 & 45.15 & 0.00 & 1.00 & 1.00 & 1.00 & 23 \\
\hline SORA & Sora & Porzana carolina & + & 0.35 & 0.07 & 0.33 & 0.47 & 4.64 & 52.68 & 0.00 & 1.00 & 1.00 & 0.91 & 70 \\
\hline SOSA & Solitary Sandpiper & Tringa solitaria & + & 0.89 & 0.21 & 0.88 & 0.91 & 3.84 & 42.99 & 0.04 & 0.88 & 0.65 & 0.40 & 8 \\
\hline SOSP & Song Sparrow & Melospiza melodia & + & 0.69 & 0.21 & 0.56 & 0.81 & 9.35 & 67.42 & 0.00 & 1.00 & 1.00 & 1.00 & 42 \\
\hline VESP & $\begin{array}{l}\text { Vesper Sparrow } \\
\text { Yellow-headed }\end{array}$ & $\begin{array}{l}\text { Pooecetes gramineus } \\
\text { Xanthocephalus }\end{array}$ & + & 0.76 & 0.42 & 0.67 & 0.81 & 10.38 & 45.70 & 0.00 & 1.00 & 1.00 & 0.99 & 13 \\
\hline YHBL & Blackbird & xanthocephalus & + & 0.45 & 0.42 & 0.49 & 0.67 & 5.88 & 18.92 & 0.00 & 1.00 & 0.99 & 0.89 & 7 \\
\hline YEWA & Yellow Warbler & Setophaga petechia & + & 0.30 & 0.10 & 0.29 & 0.57 & 4.72 & 42.96 & 0.00 & 1.00 & 0.98 & 0.86 & 44 \\
\hline
\end{tabular}


Fig. A5.1. Scatter plots representing abundance of species that were significant negative (sum(z-)) indicators of a gradient of increasing agricultural conversion in Duck Mountain, Manitoba (DMMB) at wetland (A) and landscape (B) scales.

A5.1A. Wetland scale
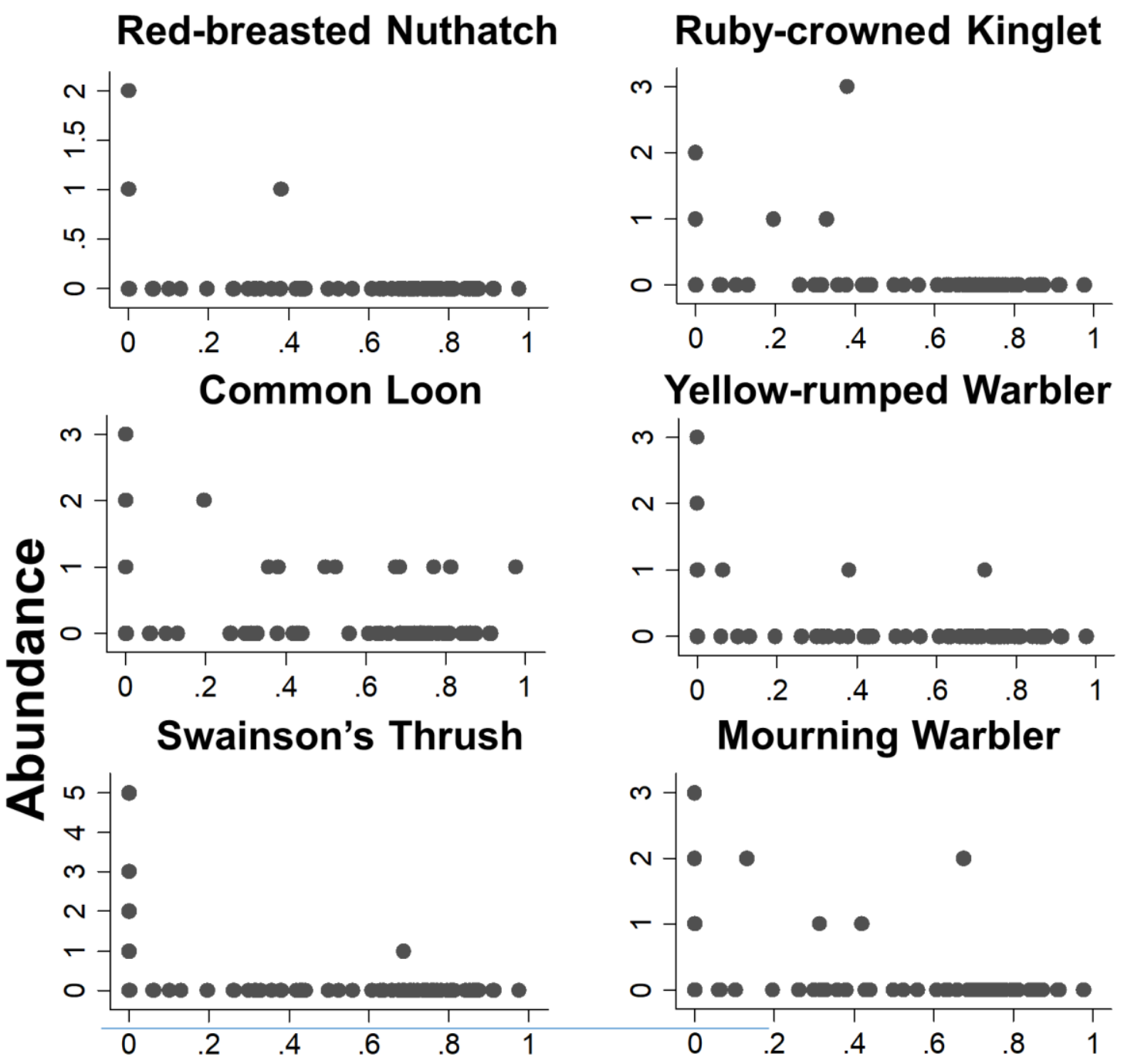

Ovenbird
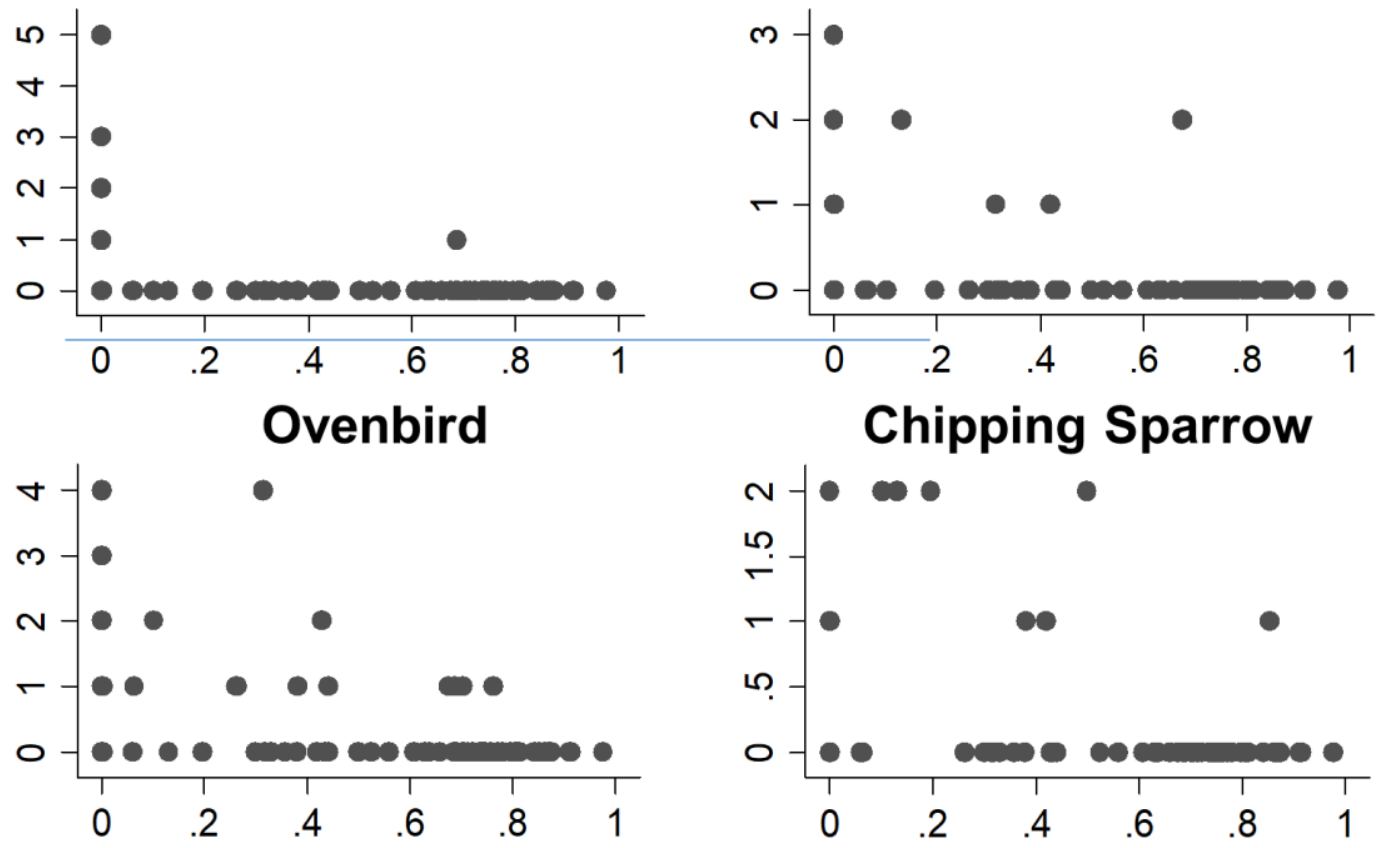

Proportion converted to agriculture

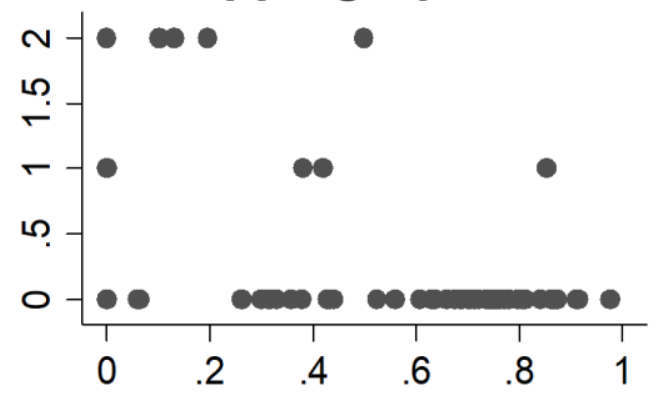



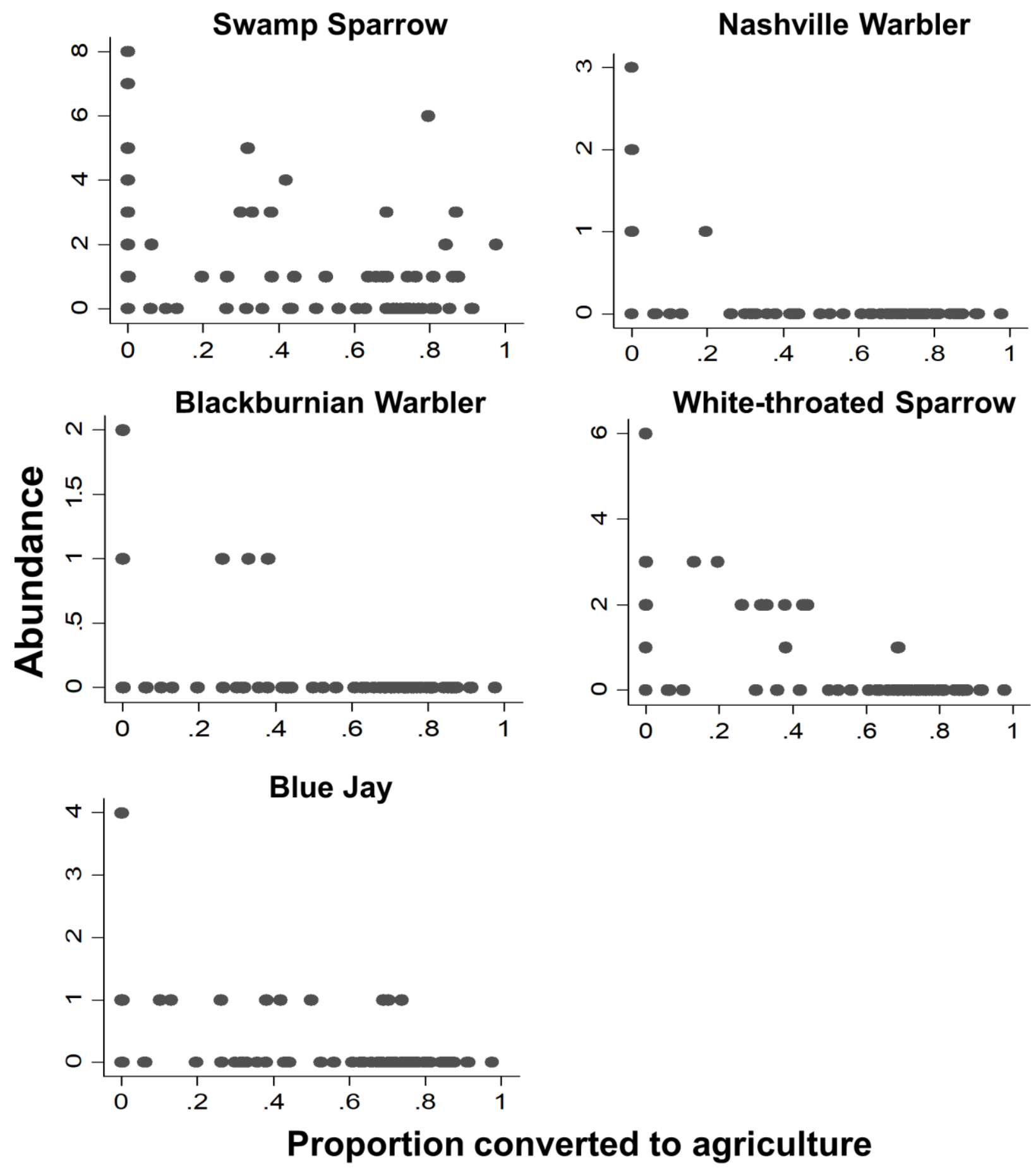
A5.1B. Landscape scale
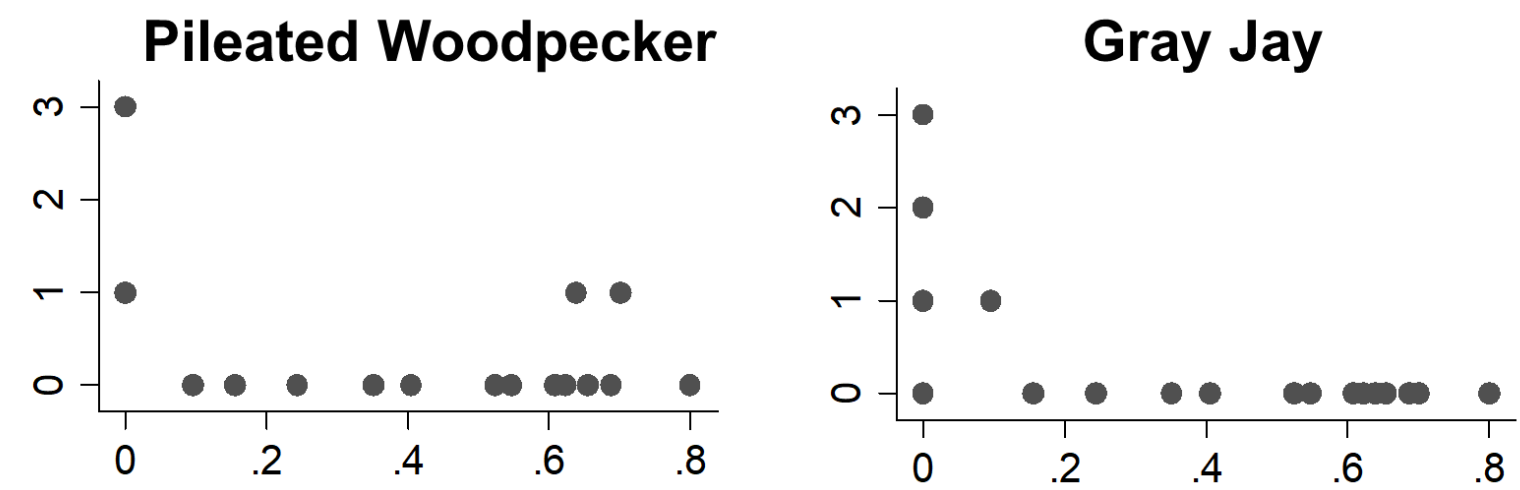

Yellow-rumped Warbler
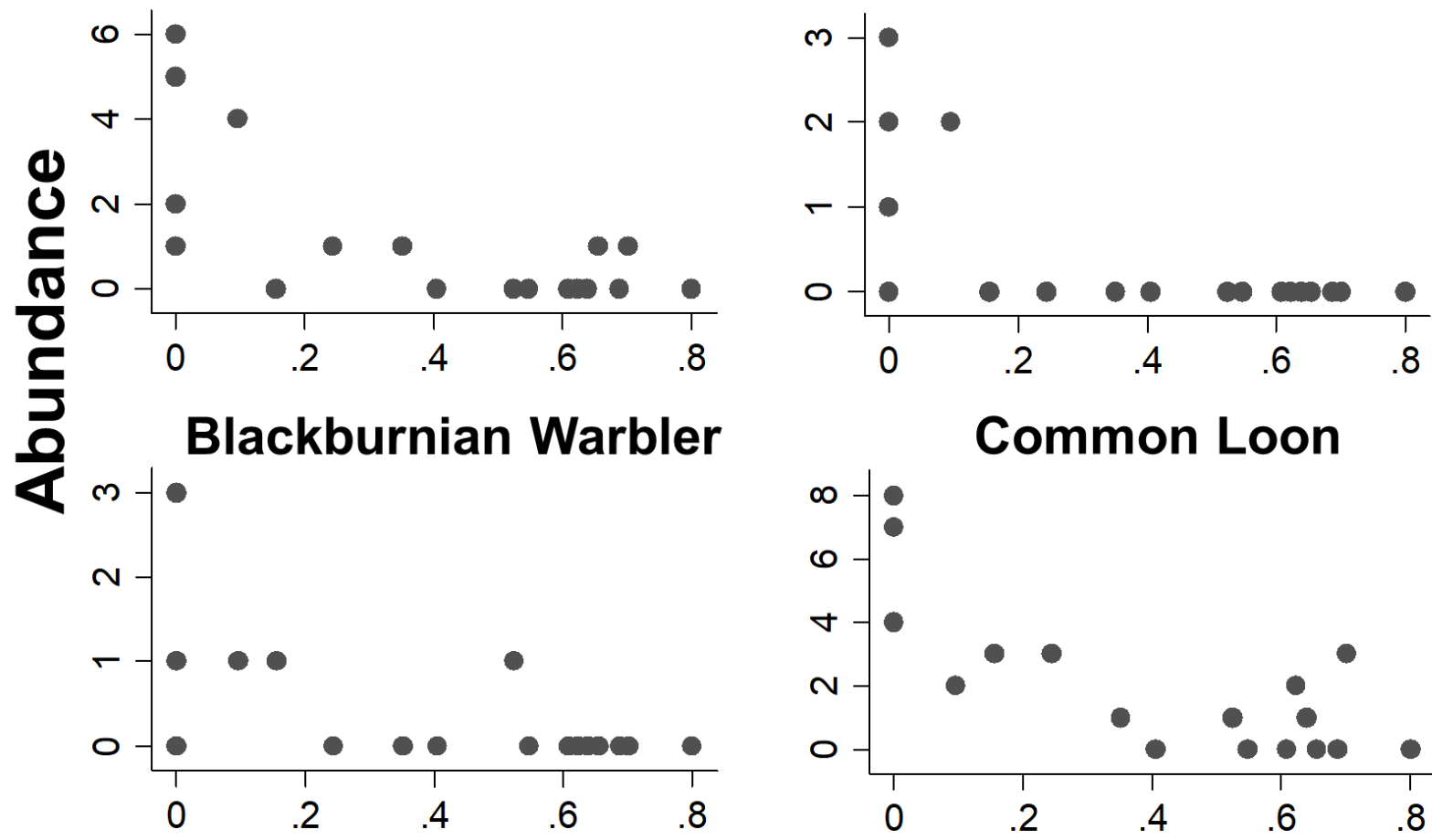

Red-breasted Nuthatch

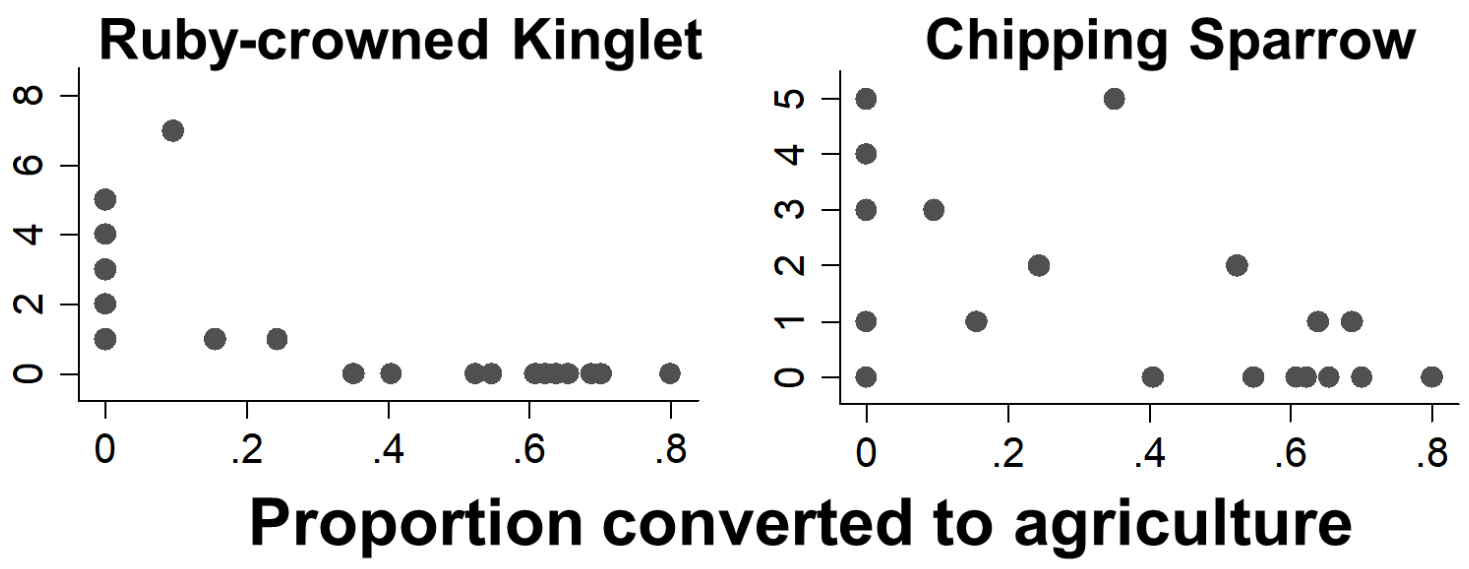




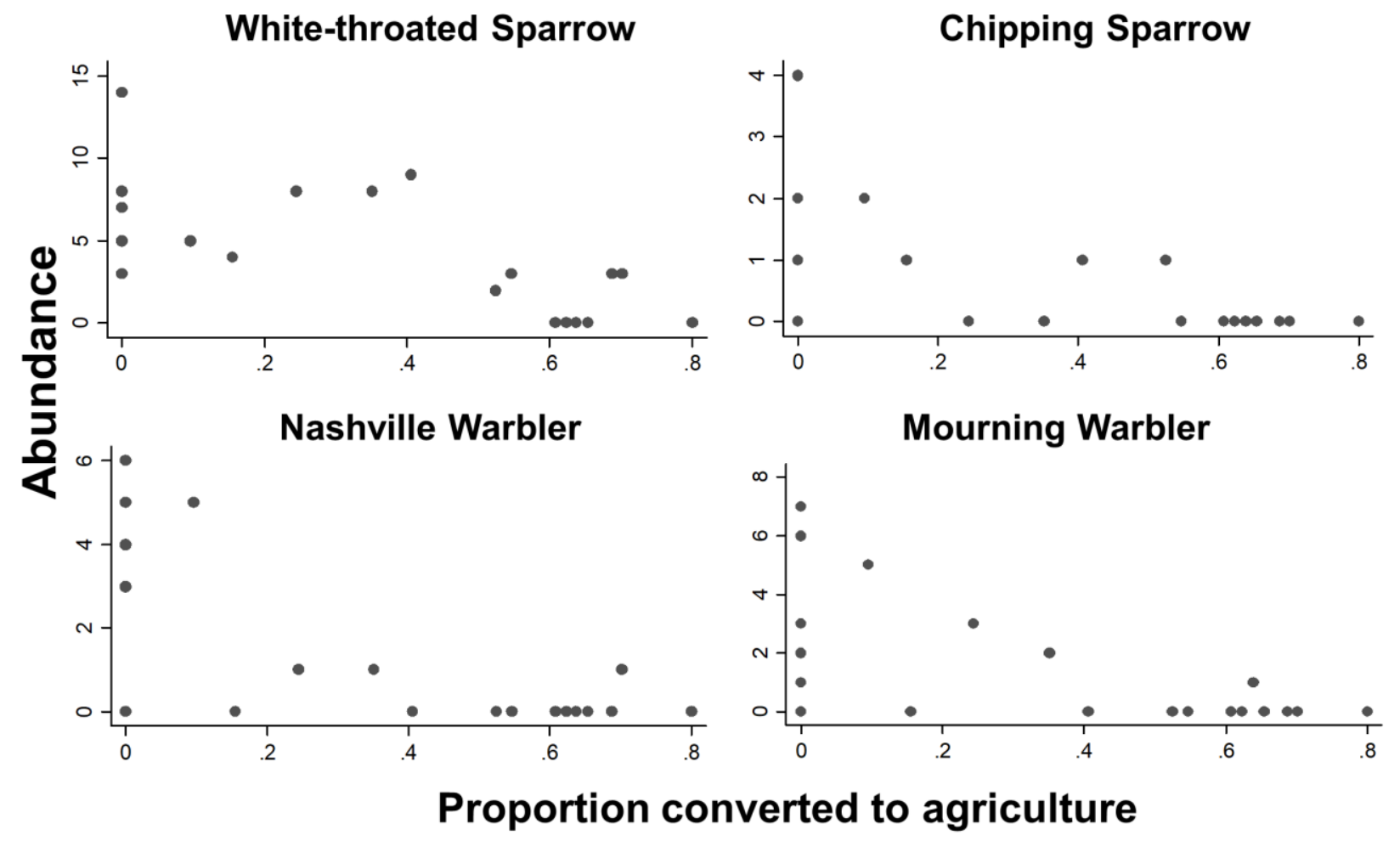


Fig. A6.1. Scatter plots representing abundance of species that were significant positive $(\operatorname{sum}(\mathrm{z}+))$ indicators of a gradient of increasing agricultural conversion in Duck Mountain Manitoba (DMMB) at wetland (A) and landscape (B) scales.

A6.1A. Wetland scale
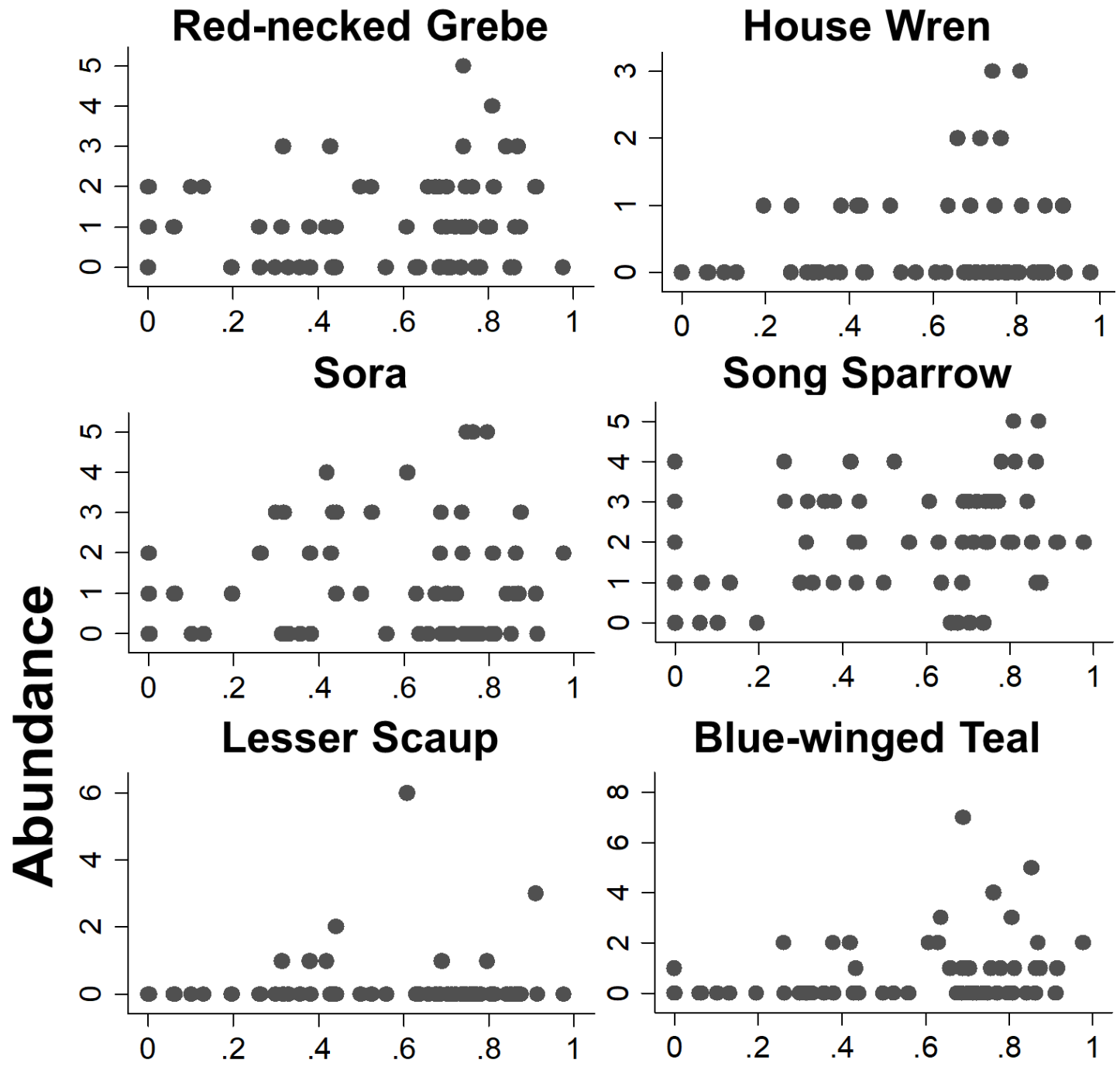

\section{Red-winged Blackbird}

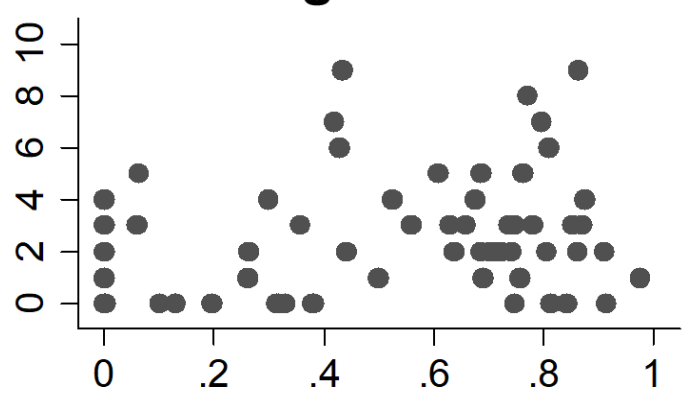

Blue-winged Teal

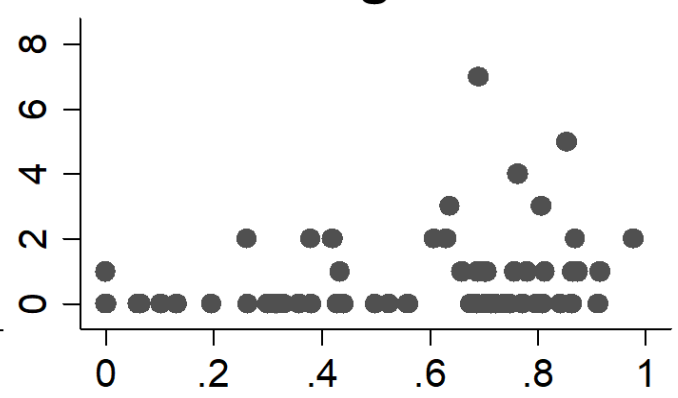

Clay-colored Sparrow

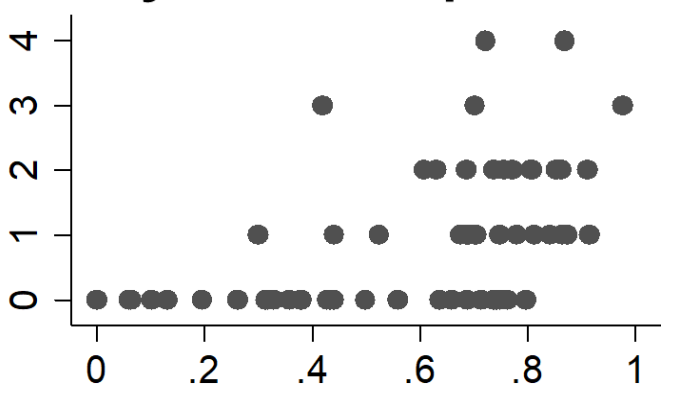

Proportion converted to agriculture 


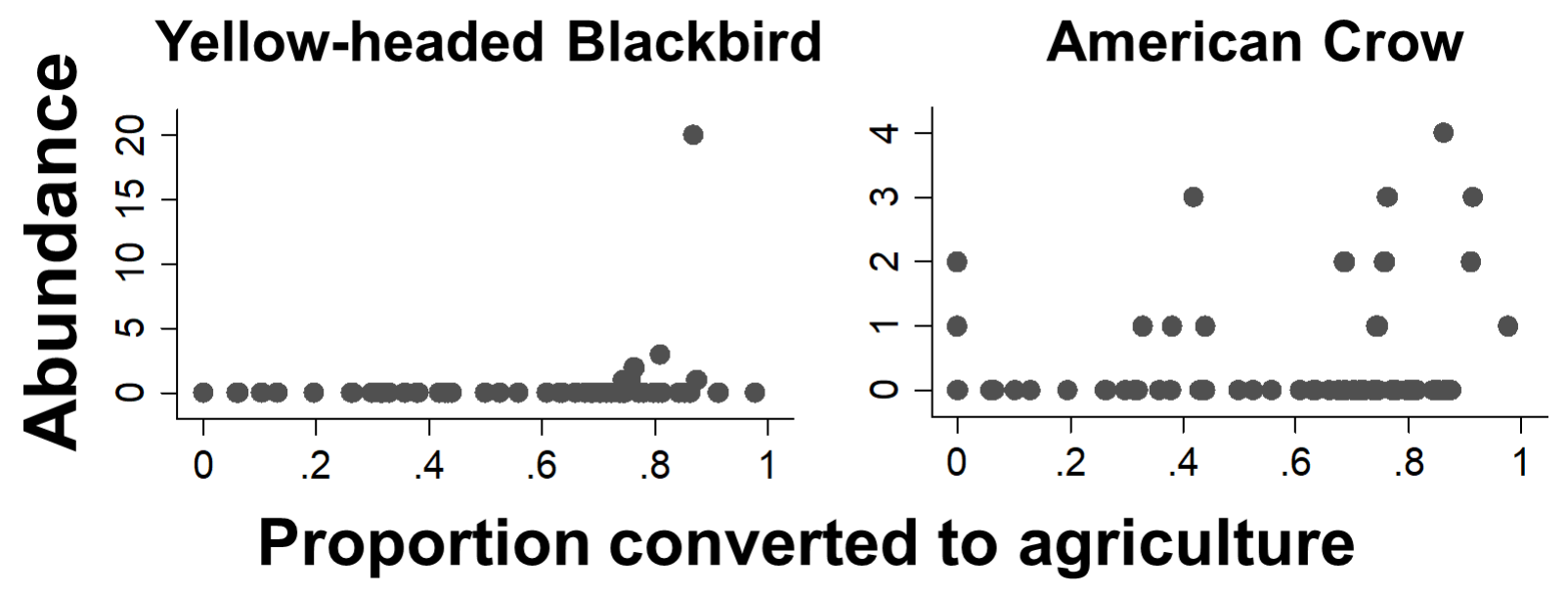


A6.1B. Landscape scale

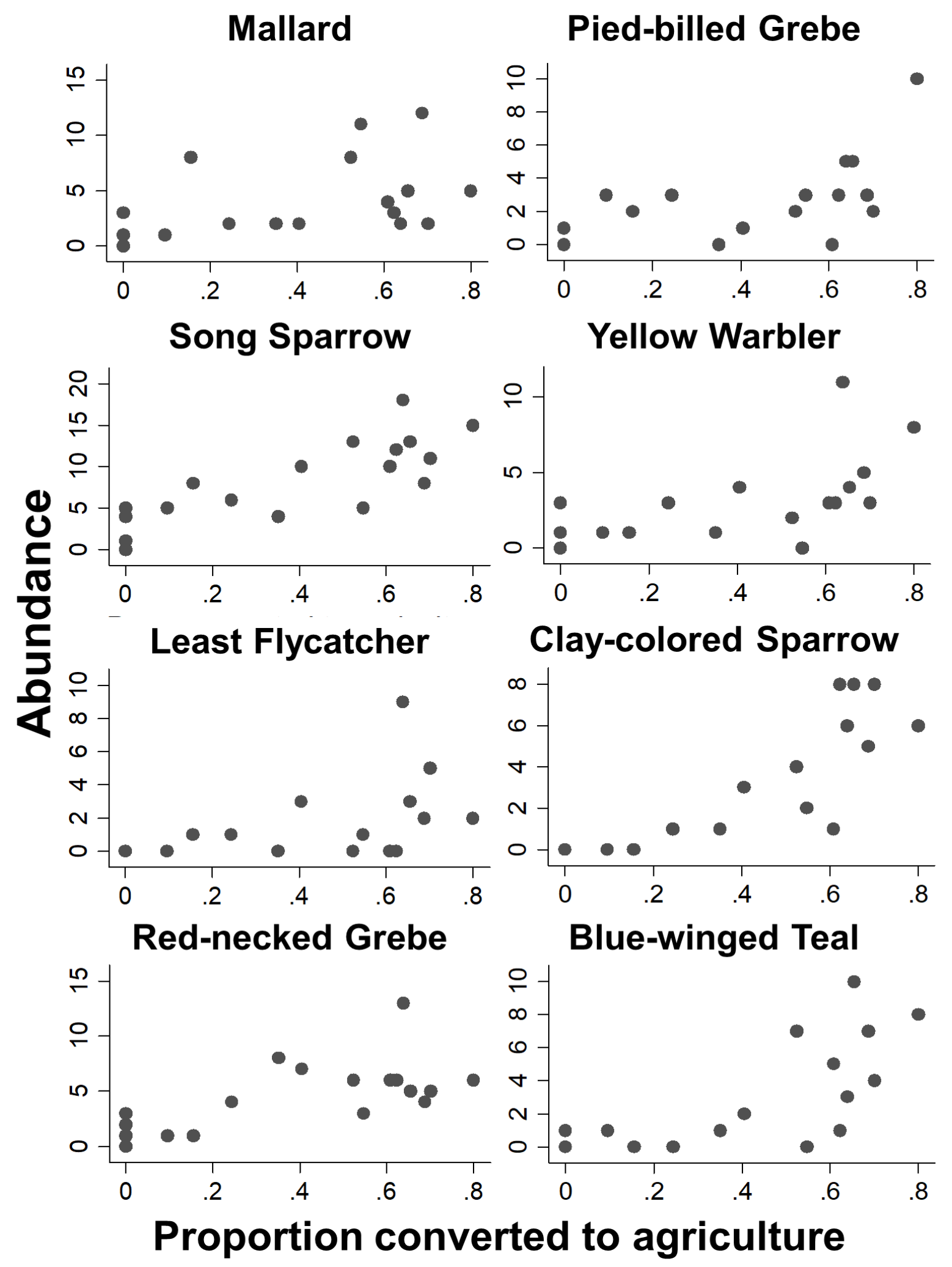

